\title{
İSTIHHZA EYLEMİ VE MÜSLÜMANLAR ÜZERİNDEKİ ETKİLERİ HAKKINDA BİR ANALİZ
}

\author{
Mehmet TÖZLUYURT \\ Dr., Diyanet İşleri Başkanlığı \\ cihathakanmz@hotmail.com
}

Öz

İstihza eylemi, geçmişten günümüze insanları toplum nezdinde itibarsızlaştırmak için kullanılan bir yöntemdir. Peygamberler gönderildikleri toplumlarda bir kaçı hariç olmak üzere kendilerine tabi olanlarla birlikte azınlıkta kalmışlardır. Vahyin ilk yılları olan Mekke dönemi de bu duruma dâhildir. İnananlar toplumda azınlıkken açiktan istihzaya ve aşağılanmaya maruz kalmışlardır. Hicretle birlikte toplumda çoğunluğu elde ettiklerinde gizli şekilde yapılan sonrasında inkar edilen istihza çeşidine muhatap olmuşlardır. İnananlar devletin tüm unsurlarına hakim olduklarında ise istihzayı ve küçümsemeyi birbirlerini karşı kullanmışlardır. Günümüzde ise istihza eylemine bazı Müslümanlarca peygamberlerin yapmadığı şekilde infazla karşılık verilmektedir. Bu tür uygulamalar İslam'ın ve Müslümanların itibarını olumsuz şekilde etkilemektedir. Bu çalışma Kur'an'ın ışı̆̆ında Hz. Peygamber'i merkeze alarak istihza eyleminin Müslümanlar üzerindeki etkilerini konu edinecektir.

Anahtar Kelimler: Peygamber; Müslüman; Hâkimiyet; İstihza; Sabır; Affetmek.

\section{AN ANALYSIS ON SARCASM AND ITS EFFECT ON MUSLIMS}

\begin{abstract}
Sarcasm is a method used to humiliate people in society from past until now. Prophets, except a few of them, were minority with those who believed them in their societies. This was the case also in first years of revelation in Mecca. People who were minority were faced to sarcasm and humiliation publicly. After the Hegira, Muslims became majority but again faced to implicit sarcasm which would be denied later. Once the believers took the control of the state, they used sarcasm against each other. Today, some Muslims retaliate the sarcasm in a harsh way that prophets did never resort to. Such approach to sarcasm affects the Muslims' and Islam's reputation in a bad way. This study, putting Prophet Muhammad in the centre, focuses on the effects of sarcasm on Muslims in the light of Qur'an.
\end{abstract}

Keywords: Prophet; Muslim; Control; Sarcasm; Patience; Forgiveness. 


\section{Giriş}

Her insan ruhu, zayıf veya güçlü olsun, manevi bir mücadele alanıdır. Burada iyi ve kötü, egemenlik kazanmak üzere sürekli birbiriyle mücadele eder. İnsanların ruhuna egemen olma mücadelesinde kötüye kıyasla iyinin iki avantajı vardır. Birincisi, kötülük işlenirken bile iyinin tanınması ve ona sayg1 gösterilmesidir. İkincisi ise bencilliğin itici olduğu gerçeğidir. ${ }^{1}$

İnsan tabiatı, öyle bir yapıya sahiptir ki, iradesiyle uyum içinde cereyan eden hiçbir şey dikkatini çekmez ve algısının konusunu teşkil etmez. Dogmalar, alışkanlıklar ve esinlenilen diğer kişiler, bireylerin davranışları üzerinde oldukça etkili olabilmektedir. Fakat bu durum, hiç bir şekilde, davranışların temel yapısını teşkil eden zihniyette köktenci bir değişim sağlamamaktadır.

Kaba, aldatılmaları kolay olan üstelik kendi aralarında çözümlenecek pek çok sorunları olan, ayrıca çok hırslı ve hasis oldukları için efendilerden vazgeçemeyen insanları sürüklemek için az bir nutuk bile yeterlidir. ${ }^{2}$ Halbuki insanla insan arasındaki ilişkilerde bir insanın başına gelebilecek en kötü olay, kendini başka birinin keyfine ve insafına bağlı bulmak olsa gerektir. 'Bir başkasının ferdi iradesine bütünüyle ve kayıtsız şartsız teslim olup boyun eğmeli' fikri kişinin kendi iradesini inkâr etmeyi kolaylaştırmanın ruhsal bir aracıdır. ${ }^{3}$ Özgürlük üzerinde düşünce yaratma kölelere düşmez.

İnsanlar arasında takdir edilme önemli bir husustur. Takdir edilmeyip alaya alınan kimse, hakarete uğramaktan doğan üzüntü nedeniyle kendisinin küçük görüldügünü hisseder. Bu, üzüntünün kendisi kadar dayanılmaz bir şeydir. Kimi insanlar kendilerinin küçük görülmesini kendisine gösterdiği saygı ile orantılı bir tarzda cezalandırdığı için intikamlar korkunç olmakta, insanlar kana susamış bir şekilde zalimleşmektedir. ${ }^{4}$

Yüce Allah, fıtratlarına yabancılaşarak hem cinsleri olan diğer insanlara insanlık dışı davranışlarda bulunanlara gerçekleri hatırlatacak peygamberler göndermiştir. Bu bağlamda Peygamberler, Yüce Allah'tan almış oldukları ilahi mesajlarla insanların istilaya uğrayan zihinlerini yeniden işlevsel hale döndürmeye çalışmaktadırlar. Zihne hâkim olup insanları yanlışlara sürükleyen olumsuz unsurlardan bir tanesi de istihza eylemidir.

\footnotetext{
Toynbee, Arnold Joseph, Hatıralar: Tanıdıklarım, çev. Deniz Öktem, (İstanbul: Klasik Yayınlar1, 2005), s. 201.

2 Rousseau, Jean Jacques, Insanlar Arasındaki Eşitsizliğin Kaynă̆̆, çev. R. Nuri İleri, (İstanbul: Say Yayınları, 2013), s. 153.

3 Schopenhauer, Artur, Hayatın Anlamı, çev. Ahmet Aydoğan, (İstanbul: Say Yayıncllık, 2014), s. 55.

$4 \quad$ Rousseau, İnsanlar Arasındaki Eşitsizlĭğin Kaynă̆ı, s. 141-142.
}

\begin{tabular}{|ccc} 
Kelâm Araştırmaları Dergisi & C.: 14, & S.: 1 \\
Journal of Kalâm Researches & V.: 14, & I.: 1 \\
[KADER-e-ISSN: 1309-2030] & 2016
\end{tabular}




\section{1. İstihza Kavramı}

Alay etmek anlaminda kullanılan kavramlardan ilki الهزء kelimesidir. el hüz', gizlilik içinde fark ettirmeden yapılan mizah demektir. İstihza; her ne kadar alay etmek hali hazırda bunu yapmak olsa da sزay etmeyi talep etmek anlamındadır. lehv ve laib (oyun ve eğlence) Allah'a izafe edilemeyeceği gibi hakiki anlamı bağlamında Allah tarafından yapılabilecek bir istihza da doğru bir mana değildir. ${ }^{5}$ Ayette geçen Allah'ın istihzası ${ }^{6}$, 'Allah onlara bu istihzalarının cezasını verecektir' anlamındadır. Bu istihzanın manası; Allah onlara günah ve isyanlarına rağmen mühlet verdi onları hemen cezalandırmadı. Onlarda bunu normal bir durum zannettiler. Ancak daha sonra onları yakalayıp kat be kat ceza verdi. Burada kâfirlere bu mühletin verilmesi istihza olarak isimlendirdi. Şöyle ki onların bu istihzalarına mühlet verilmesine aldanıp bir şey olmuyor ve olmayacak zannettiler. Sanki bu istihza onlar için bir istidrac ${ }^{7}$ gibi oldu. $^{8}$

Alay etmek anlamında kullanılan ikinci kavram ise se-ha-ra kelimesidir. Fiilin if'al kalıbı olan تسخير "teshîr", bir şeyi kendisiyle ilgili maksada zorla götürmektir. (göklerde ve yerde olanları size teshir eyledi). مسخّر , bir fiil veya bir iş için mukayyad olan tutulandır. سخريّة ise ezilen kahredilen, iradesi baskı altında tutulandır. 'sehartü minhü'; onunla alay ettim demektir. Suhriyye ve sihriyye kelimeleri; ساخر' fiilinin adlarıdır. سخر kelimesi iki farklı anlamda kullanılır: Birincisi zorla baskı altında tutmak, ikincisi ise alay etmektir. ${ }^{9}$ Suhriyye ile istihza kelimeleri eş anlamlı olarak kullanılmaktadır. ${ }^{10}$

İsfehani, Ragıb, el-Müfredat fi Garibü'l-Kur'an, nşr. Muhammed Seyyid Kîlânî, (Beyrut: Daru'l-Ma'rife, ts.), s. 542.

Hud 11/8; Nahl 16/34; Tevbe 9/65; Nisa 4/140; Rad 13/32.

İstidrac: Zalim, kâfir ve azgın kişilerin tedrici olarak felakete yaklaştırılması ve bu esnada kendilerine bazı geçici imkân ve başarıların sağlanmasıdır. Firavun örneğinde olduğu gibi (Zümer 43/46-56) istedrac sahibi kişiler elde ettikleri başarıları kendi gayretlerinin ürünü zannederler, kibirlenir ve azgınlıklarını alabildiğine artırırlar. Nihayet ilahi azaba maruz kalıp yok olurlar. Nitekim Kur'an'da genel bir ifade kullanılarak önceki milletlere de peygamberler gönderildiği, bu milletlerin hakka boyun eğmelerini sağlamak amacıyla bir süre sıkıntılar ve hastalıklarla denendikleri, daha sonra da bütün imkân kapılarının kendilerine açıldığı, nihayet alabildiğine şımardıkları bir sırada ansızın yakalanıp helak edildikleri ifade edilerek (En'am 6/42-45) istidraca dair eski toplumların hayatından örnekler verilmiştir. Özervarlı, M.Said, "Hârikulâde", TDV İslam Ansiklopedisi (DIA), XVI, 181-182.

İsfehani, Ragib, el-Müfredat, s. 543.

Bkz. İsfehani, Ragıb, el-Müfredat, s.227; İbn Manzur, Ebi'1-Fadl Cemaleddin Mükerrem b. Mükerrem el-Efrikı el-Misri, Lisanü'l-Arab, (Beyrut: ts.), III, 1963; Firuzabadi, Mecduddin Muhammed b. Yakub, el-Kamusu'l-Muhit, (Misır: El-Heyetül-Misriyytü'l-Ammetü Li'iKitabi, 1978), II, 45.

10 İbn Manzur, Lisanü'l-Arab, III, 1963; Taberi, Ebu Cafer Muhammed b Cerir, Camiu'lBeyan fi Te'vili'l-Kur'an, haz. Dr. Abdullah b. Abdu'l-Muhsin et-Türki, (Kahire: Merkezü'l-Buhusi ve'd-Diraseti'l-Arabiyyeti ve'l-İslamiyye, 2001), XI, 588.

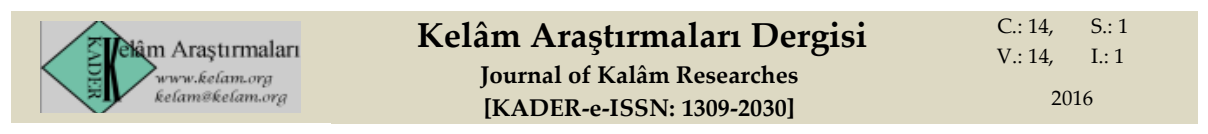


Kur'an'1 Kerim'de on bir ayette 'hüzüv' kelimesi, yirmi üç yerde 'istihza' mastarından türemiş fiil ve isimler geçmektedir. Ayrıca on beş ayette 'suhriyye' kökünden isim ve fiiller yer almaktadır. ${ }^{11}$

Alay edenin alay edilene zahiren (görünüşte) onun razı olacağı ve onun tasdik edeceği sözü söylemek veya işi yapmaktır. Alay eden bu söz ve davranışı ile batınen (gizliden) karşısındakinin kötülüğünü ve onu zor duruma düşürmeyi istemektedir. ${ }^{12}$

İstihza konusu, gerek Hz. Peygamberin gerekse önceki peygamberlerin tebliğ ve elçiliklerini başarısız kılmak üzere inkârcıların başvurduğu psikolojik bir savaş taktiğidir.13 Alay etmek, değer vermemek ve önemsememekten kaynaklanır. İnsanlar Allah kelamını ve peygamberleri alay ederek veya kalpleri başka şeylerle meşgul olarak dinliyorlarsa söylenenleri duymayacaklar, bunu idrak edemeyeceklerdir. ${ }^{14}$

\section{Hz. Peygamber Öncesi İstihza}

\section{a) İblis'in Hz. Âdem'i İstihzası}

İstihzanın İblis ${ }^{15}$ ile başladığını söylesek yanılmış olmayız. Hz. Âdem, Allah'tan almış olduğu bilgilerle bütün varlıkların isimlerini melekler ve iblisin hazır bulunduğu bir ortamda söylemiştir. ${ }^{16}$ İblis ve melekler $\mathrm{Hz}$. Âdem'in sahip olduğu ilim karşısında mağlup olmuşlardır. İblis, Meleklerin aksine mağlubiyetini gölgelemek için dikkatleri başka tarafa çekmeye gayret etmiştir. "Allah, "Sana emrettiğim zaman seni saygı ile eğilmekten ne alıkoydu?" dedi. O da "Ben ondan hayırlıyım. Çünkü beni ateşten yarattın. Onu ise çamurdan yarattın" dedi."17 Alay etmede kabul etmeme düşüncesi ön plandadır. İblis'in Hz. Âdem'e secde etmemesinin altında bu gerçek yatmaktadir.

11 Abdülbaki, M. Fuad, el-Mu'cemu'l-Müfehres li Elfazi'l-Kur'ani'l-Kerim, (İstanbul: Çağrı Yayınları, 1990), Sin ve He maddeleri.

12 Taberi, Camiu'l-Beyan, I, 315.

13 Çağrıcı, Mustafa, "İstihza”, TDV İslam Ansiklopedisi (DIA), XXIII, 347-348. (Ey Muhammed!) Andolsun, senden önce de birçok peygamber alaya alınmıştı da onlarla alay edenleri, alay ettikleri şey kuşatıp mahvetmişti. En'am 6/10; Ayrıca bkz. Hicr 15/11; Yasin 36/30.

14 Kurtubi, Ebi Abdillah Muhammed b. Ahmed b. Ebi Bekir, el-Camiu li-Ahkami'l-Kur'an haz. Dr. Abdullah b. Abdu'l-Muhsin et-Türki, (Beyrut: Müessesetü'r-Risale 2006), XIV, 172-173.

15 Kur'an'da şeytanlar için kullanılan İblis tanımlaması özellikle Hz. Âdem'e secde emrine karşı gelen varlık için kullanılır. Hz. Âdem'e secde edilmesini anlatan kıssa, geçtiği hemen tüm surelerde emre itaatsizlik eden varlık için İblis tanımlamasını kullanır. Yani şeytandan ilk olarak İblis ismiyle bahsedilir. "Şeytan" kelimesi ise, "şeyatîn" şeklindeki çoğul formuyla beraber Kur'an'da 88 kez geçmektedir. Hüseyin Aydın, "Meleklere İman", İslam İnanç Esasları, Ş. Ali Düzgün (ed.), (Ankara: Grafiker Yayınları, 2013), s.140.

$16 \quad$ Bkz. Bakara 2/31-33.

$17 \quad \operatorname{Rad} 7 / 12$.

$\begin{array}{ccc}\text { Kelâm Araştırmaları Dergisi } & \text { C.: 14, } & \text { S.: } 1 \\ \text { Journal of Kalâm Researches } & \text { V.: 14, } & \text { I.: } 1 \\ \text { [KADER-e-ISSN: 1309-2030] } & 2016\end{array}$


Yazır, İblis'in itirazını şu şekilde açıklamaktadır: "Ateş çamurdan hayırlıdır. Hayırlıdan yaratılan da hayırlıdır. Şu halde ateşten yaratılan ben, çamurdan yaratılan Âdem'den hayırlıyım, bunun için secde etmiyorum." Demek oluyor ki, bu zamana, yani Âdem'e secde emrinin gelmesine kadar Allah Teâlâ, İblisin duygularına dokunacak hiçbir emir ve teklif yapmamış, imtihan etmemiş idi. Onun o zamana kadar isyan etmemesi ve melekler içinde bulunması, olayların kendi arzu ve eğilimlerine uygun gerçekleşmesiyle de ilgili bulunuyordu. Böyle bir durumda olan taatın ise sadece emir ve ilahi rızaya boyun eğmekten kaynaklandığı ortaya çıkamazdı. Çünkü hem Allah'ın emrine hem de nefsin arzularına uygun gelen hususlarda asıl göz önüne alınıp itaat edilen ma'bud, Allah mı, yoksa nefis mi bu belirlenemez ve açıklığa kavuşamaz. Ne zaman ki Âdem yaratılıp meleklerin ve o meyanda İblisin ona secde etmeleri emredilince, bu hepsi için imtihan olmuş, bu imtihan İblisin duygularına dokunmuş ve iç yüzünü ortaya çıkarmıştır."18

Hz. Âdem'in Yüce Allah katındaki aşırı değeri ${ }^{19}$ İblis tarafından kendisine tuzak kurulmasına sebep oldu. Allah Teâla'nın Âdem ve eşini ağaçla imtihana tabi tutması Âdem'in Allah katındaki itibarını yok etmek için iyi fırsattı. "Derken, şeytan ayaklarını oradan kaydırdı. Onları içinde bulundukları konumdan çıkardı. Bunun üzerine biz de, "Birbirinize düşman olarak inin. Sizin için yeryüzünde belli bir süre barınak ve yararlanma vardir" dedik." 20

Hz. Âdem bu itibar kaybının sebebi olarak kendi nefsini görmüştür. Allah Teâla'dan, tevbe ederek af diledi. İblis'e her hangi bir suç atfetmedi. ${ }^{21}$ Âdem adına İblis'e karşılık veren Yüce Allah olmuştur. "Allah, "Şimdi in aşağı oradan. Çünkü senin orada büyüklük taslamak haddine değil! Hemen çık! Çünkü sen aşağıllıklardansın" dedi.22 Şeytan cennetten kovulurken aklına göre değil duygularına göre hareket etmiş sonuçta yanılmıştır.

\section{b) Önceki Kavimlerin Peygamberlerini İstihzası}

Her peygamber gönderildikleri toplumları, bir olan Allah'ı tanımaya ve O'na kulluk etmeye davet etmişlerdir. Bu uğurda birçok sıkıntıyla karşı karşıya kalmışlardır. Bunlardan birisi de gönderildikleri topluluklarca alaya alınmalarıdır. Uyarılara karşı kulak tıkama eylemi inanmayanların peygamberlere karşı uyguladıkları yıldırma politikasıdır. Peygamberler

18 Yazır, Elmalılı Muhammed Hamdi, Hak Dini Kuran Dili, (İstanbul: Eser Yayınevi, 1979), III, 2013-2133.

19 “Andolsun, biz insanoğlunu şerefli kıldık. Onları karada ve denizde taşıdık. Kendilerini en güzel ve temiz şeylerden rızıklandırdık ve onları yarattıklarımızın birçoğundan üstün kıldık." İsra 17/70.

Bakara 2/36; Araf 7/13.

Bakara 2/37; Araf 7/23.

Araf 7/13 krş. Bakara 2/38.

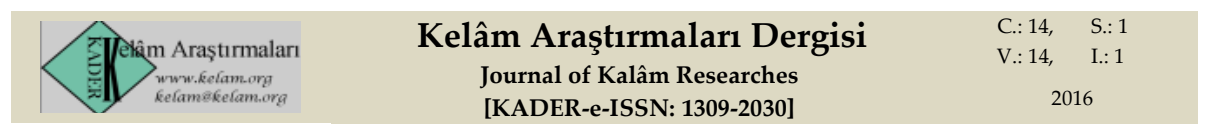


silsilesi düşünüldüğünde bu durum kimilerince bir ahlak haline gelmiştir.23 "Andolsun, senden önce de birçok peygamberle alay edildi de içlerinden alay edenleri, o alaya aldıkları şey kuşatıverdi." 24

Hayatta her şeyin bir bedeli vardır. Bir şey ne kadar iyi ve değerli olursa, bedeli büyük ve sorumluluğu da o kadar ağır olur. Herkes yaşadığı dönemde ürettiği bir şey karşılığında başkalarının saygısını kazanabilir. Bunun en güzel örneği peygamberlerdir. Çünkü onlar bulundukları ortamlarda ahlaki özellikleri ile birçok insanın gönlünü islama 1sındırmışlardır. Allah, tebliğ görevini yerine getirmeye çalışan peygamberlerini uyarmakta ve çağrıya kulak vermeyenler için kendilerini üzmemelerini istemektedir. ${ }^{25}$

Alay edenler peygamberleri ve inananları kendilerine boyun eğdirmek için istihza yöntemine başvurmuşlardır. Başkalarına emretmek peşinde olmayan insana boyun eğdirmek çok zor olsa gerektir. Kur'an'da isimleri ve kıssaları anlatılan tüm peygamberlerin davette bulundukları insanları ezmek ve onlara emretmek gibi hedefleri olmamıştır. Çünkü ilahi mesajlar zahiri bir ihtişam meydana getirmek veya ruhani egemenliği ele geçirmek yahut zorlayıcı kuvvet uygulamak için değildir. Aksine insanların hayatını erdem ve dindarlık kurallarına göre düzenlemek için gönderilmiştir. ${ }^{26}$

Bir kısım insanların içinde yaşadığı bolluğun arkasında, alaya aldıkları insanların yoksulluğ $\mathrm{u}^{27}$ olsa gerektir. Böyle bir birey, hakikati kendine göre tanımlar ve onun için kendisinden daha önemli bir şey yoktur. $O$, dünyayı sadece kendi bakış açısına göre algılar. Bu sebeple de aslında oldukça küçülür. Halbuki daha iyi bir toplum kurmak ve daha yaşanılır bir dünyaya kavuşmak için bireyin durumunu iyileştirmek gerektir.

İnsanlar tanımadıkları veya tanımak istemedikleri farklı kültür veya din sahipleri ile veya karşıt oldukları düşünce ile mücadele ederler. Karşı taraftan ne isterlerse onu yapmaların beklerler. Onların bu istekleri alay ve aşağılama doludur. Onların bu tavırları cehaletten kaynaklansa ${ }^{28}$ gerektir. Bütün amaçları yaşadıkları dünya hayatı olan, zevkine düşkün ve gamsız insanlar için ilerideki ebedi hayatın tek gerçek olduğunu anlatan bir dinin ve onun taraftarlarının alay konusu olması doğal olsa gerektir.

İstihzaya maruz kalan elçilerden bir tanesi Hz. Nuh'tur. Hz. Nuh Allah'tan almış olduğu emirle ve O'nun gözetiminde gemi yapmaya başlamıştır.

23 Enbiya 21/2, 36; Kurtubi, el-Camî, XIV, 180, 202, 207.

24 Enbiya 21/41; Hicr 15/11. “Andolsun, senden önce de nice peygamberler alaya alındı da ben inkâr edenlere bir süre (mühlet) verdim, sonra da onları yakalayıverdim. Benim cezalandırmam nasılmış!" Rad 13/32.

25 Furka 25/44; Yunus 10/42.

26 John Locke, Hoşgörü Üstüne Bir Mektup, çev. Melih Yürüşen, (Ankara: Liberte Yayınları, 2012), s. 28.

27 Rousseau, İnsanlar Arasındaki eşitsizliğin Kaynağı, s.25.

$28 \quad$ Bkz. Ahkaf 46/23-24.

\begin{tabular}{|ccc} 
Kelâm Araştırmaları Dergisi & C.: 14, & S.: 1 \\
Journal of Kalâm Researches & V.: 14, & I.: 1 \\
[KADER-e-ISSN: 1309-2030] & 2016
\end{tabular}


Kavminin ileri gelenleri her ne zaman yanına uğrasalar, 'peygamberlikten sonra marangoz mu oldun, karada gemiyi ne yapacaksın' diyerek onunla alay etmekteydiler. Onların yaptıkları, tahminlerden yola çıkarak insanlara olası gerçekler öne sürmekten ibarettir. Allah, Hz. Nuh'un kavminin kendisi ile alay etmesine karşılık onun yanında olduğu mesajını vermektedir. İnanmayanların yapmakta oldukları şeylerden dolayı üzülmemesini istemektedir. İnanmayanlar inananlarla bu dünyada alay edenlerken, ahirette tam tersi bir durum yaşanacaktır. Bu defa inananlar kendilerini küçümseyenlerle alay edeceklerdir. ${ }^{29} \mathrm{~Hz}$. Nuh'a düşen ise Allah tarafından kendisine verilen emre itaat etmesidir.

Allah'ın elçilerince insanlara ne kadar iyi niyet ve şefkat gösterilirse gösterilsin insanlar istemedikçe kurtulmaya, doğru yolu bulmaya zorlanamazlar. Tanrı hiç kimseye bir başkasını kendi dinine zorlamaya yönelik açık bir otorite ${ }^{30}$ vermemiştir. Hakiki dinin bütün hayatı ve gücü, aklın samimi ve tam olarak ikna edilmesine bağlıdır. ${ }^{31}$ Çünkü efendiler tarafından yönetilmeye alışmış olan insanlar, onlardan vazgeçmekte zorlanacaklardır. Bundan dolayı yapılacak şey bunun onların vicdanlarına bırakılmasıdır. Vicdanlarının sesini dinleyerek insanlar gönüllü olarak veya baskıyla katıldığı topluluğun doktrininde yanlış olan veya ibadetine aykırı gelen her hangi bir şey bulduğunda bu topluluğu terk edebilmelidir. ${ }^{32}$

Kimi insanlar gözlerinin önünde bulunan bazı insanların kendi kulluklarına nasıl sabırla katlandıklarına bakıp, kulluğu ve köleliği doğal bir eğilim saymaktadırlar. ${ }^{33}$ Kölelik bağları, insanların karşılıklı bağımlılıklarından, karşıllklı gereksinmeler onları birleştirmeden önce meydana gelmez. Bu sebeple bir insanı daha önce başka bir insandan vazgeçemeyecek bir duruma getirmedikçe kul edip köleleştirmek imkânsızdır. ${ }^{34}$ Hakim otoriteye kulluk eden insanlar yönlerini başka tarafa çevirdiklerinde, derhal itibarsızlaştırılmaktadırlar. "Kavminden ileri gelen kâfirler dediler ki: “Biz seni sadece bizim gibi bir insan olarak görüyoruz. Bizden, basit görüşle hareket eden alt tabakamızdan başkasının sana uyduğunu görmüyoruz. Ve

29 Bkz. Hud 11/36-38; Bkz. Taberi, Camiu'l-Beyan, XII, 393.

30 "O yarattıkları üzerinde otorite sahibidir" (En'am, 6/18) ayetindeki otorite; Allah'ın, kudret ve hikmetinin mükemmel olduğuna delalet etmektedir. Üstünlük ise, kudret ve hâkimiyet bakımından üstünlük olup, mekân bakımından yukarıda olma anlamında değildir. Tıpkı "efendi, kölenin üstündedir" sözünde anlaşılan üstünlük gibi. Burada "Kullarının üstündedir" ifadesi "kudret ve üstünlükle Allah'ın yüceliğini ve otoritesini tasvir etmek için kullanılmıştır. Bkz. Zemahşeri, Muhammed b. Ömer, el-Keşşaf an Hakaiki Gavamizi't-Tenzil ve Uyuni'l-Ekavil fi Vücuhi't-Te'vil, (Beyrut: Daru İhyai't-Türasi'1Arabiyye, 2003), I-II, 321.

31 Locke, Hoşgörü Üstüne Bir Mektup, s. 32-33.

32 Locke, Hoşgörü Üstüne Bir Mektup, s. 35,52.

33 Rousseau, İnsanlar Arasındaki Eşitsizliğin Kaynağı, s. 158. Efendiler tarafından yönetilmeye alışmış olan insanlar, onlardan vazgeçmekte zorlanacaklar.

34 Rousseau, İnsanlar Arasındaki Eșitsizliğin Kaynağı, s. 129.

$\begin{array}{|ccc|}\text { Kelâm Araştırmaları Dergisi } & \text { C.: 14, } & \text { S.: } 1 \\ \text { Journal of Kalâm Researches } & \text { V.: 14, } & \text { I.: } 1 \\ \text { [KADER-e-ISSN: 1309-2030] } & 2016\end{array}$


sizin bize karşı bir üstünlügünüzü de görmüyoruz. Bilakis sizin yalancılar olduğunuzu düşünüyoruz." 35

Maturidi, Hud suresi 27 ayette doğruluğu seçen insanların ileri gelenlerce nasıl hafife alındıklarını şu şekilde yorumlamaktadır: "Toplumun ileri gelenleri zikri geçen ayeti peygamberliğin reddi için delil getirmektedirler. Onlara göre 'erazil', kendilerini çağıran kimselerin tamamına tabi olan ve tabi olunmuş kimselere itaat eden halktır. Sadece 'erazil' ve zayıfların tabi olmasında peygamberliğin sabit olması için delil yoktur. Çünkü onlar delil ve hüccet olmadan peygambere tabi olmaktadır. Halbuki bu erazil grubu yanında mal ve dünyalıklar bulunmayan peygamberlere tabi olmakta, beraberinde mal ve dünya nimetleri olan ileri gelenlere ve reislere tabi olmamaktadırlar. Sonrasında da kendisine çağırdıkları mal ve dünyalıklar ellerinde olduğu halde ileri gelenlere ve reislere tabi olmayı terk ettiler. Peygamberlere tabi oldular. Bu durum onların, peygamberlerin kendilerine karşı yerine getirdikleri hüccetle ve delillerle peygamberlere tabi olduklarına işaret etmektedir." 36 Peygamberlerce eşitsizliğe karşı yapılmış olan her başkaldırı ayrıcalıklı sınıfların kararlı direnciyle karşı karşıya kalmıştır. ${ }^{37}$

Kavmi tarafından alaya alınan peygamberlerden birisi de Hz. Musa'dır. Hz. Musa, Yüce Allah'ın yardımıla kavmini Firavun'un zulmünden ve aşağılamasından kurtarmıştır. ${ }^{88}$ İsrailoğulları bu sayede Allah'ın nimetlerine kavuşmuştur. Allah, içlerinden bir peygamber çıkararak onları bulundukları toprakların hâkimleri kıldı. Diğer toplumların hiçbirine verilmeyen onların emrine verildi ${ }^{39} \mathrm{~Hz}$. Musa bütün bu nimetlere rağmen nankörlük eden kavmi tarafından birçok kez yalnız bırakılmıştır. Bu durumun örneği Kur'an'ı Kerim'im Maide suresinde şöyle yer almaktadır: “Ey kavmim! Allah'ın size yazdığı kutsal toprağa girin. Sakın ardınıza dönmeyin. Yoksa ziyana uğrayanlar olursunuz." Dediler ki: "Ey Musa! O (dediğin) topraklarda gayet güçlü, zorba bir millet var. Onlar oradan çıkmadıkça, biz oraya asla giremeyiz. Eğer oradan çıarlarsa, biz de gireriz." Korkanların içinden Allah'ın kendilerine nimet verdiği iki adam şöyle demişti: "Onların üzerine kapıdan girin. Oraya girdiniz mi artık siz kuşkusuz galiplersiniz. Eğer mü'minler iseniz, yalnızca Allah'a tevekkül edin." Dediler ki: "Ey Musa! Onlar orada bulundukça, biz oraya asla girmeyeceğiz. Sen ve Rabbin gidin, onlarla savaşın. Biz burada oturacağız." 40

\footnotetext{
35 Hud 11/27. Yoksullar çoğunluk olmaktan çıktığında demokrasi eşitliğin düşmanı haline gelir. Alex Callinicos, Eşitlik, çev. Öncel Sencerman, (Ankara: BilgeSu Yayınları, 2014), s. 16.

36 Maturidi, İmam Ebu Mansur Muhammed b. Muhammed b. Mahmud, Te'vilâtü Ehli Sünne, haz. Mücdi Bâsellum, (Beyrut: Daru'l-Kütübi'l-İlmiyye, 2005), VI, 121. Bkz. Callinicos, Eşitlik, s.43.

Şuara 26/62-65.

Maide 5/20.

Maide 5/21-24
}

\begin{tabular}{|c|c|c|}
\hline 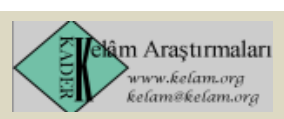 & $\begin{array}{l}\text { Kelâm Araştırmaları Dergisi } \\
\text { Journal of Kalâm Researches } \\
\text { [KADER-e-ISSN: 1309-2030] }\end{array}$ & $\begin{array}{c}\text { C.: } 14, \quad \text { S.: } 1 \\
\begin{array}{c}\text { V.: } 14, \quad \text { I.: } 1 \\
2016\end{array}\end{array}$ \\
\hline
\end{tabular}


Hz. Musa'nın kavmi her ne kadar Bir olan Allah'a iman etmişlerse de eskiden kalma bazı alışkanlıklarını devam ettirmekteydiler. ${ }^{41}$ Buzağıyı mukaddes bir hayvan olarak kabul ediyorlardı. Hz. Musa, Allah'ın onlardan bir sığır kesmesini istediğini söyleyince şaşa kaldılar. Çünkü onlar sığırın kurban edilebileceğini hayal dahi edemiyorlardı. Zihinlerde ihtilal meydana getirecek böyle bir emri yerine getirmek onlar için hiç de kolay değildi. Hz. Musa'nın kavmi henüz sığır kesilmesini içine sindirebilecek ve bu işten memnun olacak durumda değillerdi. Ayrıca bunda Allah tarafından bir hayır olduğunu anlayabilecek akli düşünceden yoksundular.

Zihniyeti 1slah etmeye yönelik ve sonuç itibariyle ölünün yeniden dirilmesine örnek vererek fitneyi ortadan kaldıracak olan bu sığır kurban edilmesi emrini duydular. Hz. Musa'ya karşı, böyle bir şey olur mu, sen bizimle alay mı ediyorsun? diye durumu tuhaf karşıladılar. Hz. Musa'ya inanmadılar. ${ }^{42}$ Onlar peygamberlerini alay eden olarak isimlendirdiler. Her kim elçilerden herhangi birini alay eden olarak isimlendirirse inkar etmiş olur. ${ }^{43} \mathrm{~Hz}$. Musa kavmine, "Kendini bilmez cahillerden olmaktan Allah'a sığınırım" diyerek kendisinin alay eden değil yalnızca ilahi emirleri tebliğ ile görevlendirildiğini, bu tebliğin basit bir tebliğ olmadığını anlatmak istedi. ${ }^{44}$

Hz. Musa, Yüce Allah'a kendisinden ve kardeşinden başkasına söz geçiremeyeceğini belirtmiştir. O'ndan, yoldan çıkmış olanlarla ve kendi yanlış fikirlerine göre hareket edenlerle arasını ayırmasını istemiştir. ${ }^{45} \mathrm{Bu}$ durum çeşitli insan faaliyetleri hakkında yapılan tartışmalarda 'nesnel' değerlendirmelerle bir yere varılamayacağının en güzel ispatıdır. Hiçbir peygambere bazı durumlarda bir şeyin doğruluğunu veya yanlışlığını ortaya koymak yerine tarafsız kalması yakışmaz.46 Yüce Allah yoldan çıkmışlara çeşitli bahaneler üreterek girmekten çekindikleri beldeyi kırk yıl haram kılmış, bu süre içinde yeryüzünde şaşkın şaşkın dönüp dolaşma cezası vermiştir. ${ }^{47}$

Bir dinin prensiplerini kabul eden bireyler o dinin prensiplerini yerine getirip getirmeme konusunda Yaratıcıya karşı sorumludurlar. Dînî hükümleri uygulama konusunda zaaf gösteren insanlar, o dine hiç girmemiş kişilere göre daha fazla aşağılanmakta ve cezalandırılmaktadır. Şöyle ki Yahudi toplumunda putperestlerin durumu iki farklı kategoride değerlendirilmekteydi. Birinci gruptakiler, Musevi ayinlerini, örflerini öğrenerek Museviliğe kabul edilmiş, bu toplumun vatandaşı sıfatını

41 İnsanların karakterlerini değiştirmek mümkün olsaydı, o zaman onca dindar insanın ve onca ahlaklılığı savunan kişinin çabaları sonuçsuz kalmazdı. Arthur Schopenhauer, Merhamet, çev. Zekai Kocatürk, (İstanbul: Dergâh Yayınları, 2014), s. 135.

$42 \quad$ Bakara 2/67; Yazır, Hak Dini, I, 381-382.

43 Maturidi, Te'vilât, I, 490.

$44 \quad$ Yazır, Hak Dini, I, 382.

45 Maide 6/25.

46 Toynbee, Hatıralar: Tanıdıklarm, s. 131-132.

47 Bkz. Maide 6/26.

\begin{tabular}{|c|c|c|}
\hline (elâm Araştırmaları & $\begin{array}{l}\text { Kelâm Araştırmaları Dergisi } \\
\text { Journal of Kalâm Researches } \\
\text { [KADER-e-ISSN: 1309-2030] }\end{array}$ & $\begin{array}{c}\text { C.: } 14, \quad \text { S.: } 1 \\
\begin{array}{c}\text { V.: } 14, \quad \text { I.: } 1 \\
2016\end{array}\end{array}$ \\
\hline
\end{tabular}


kazanmış, fakat sonradan İsrail Tanrısına ibadetten yüz çevirmiş olanlardır. Bunlar hain ve asi olarak dava edilmekte, suçları da en ağır ihanetten hafif kabul edilmemektedir. İkinci gruptakiler, İsrail devletine yabancı olanlardır. Bunlar Musevi yasasının kurallarına uymaya zorlanmamışlardır. Aksine putperest olan bir İsraillinin öldürülmesinin emredilmesine karşllık yabancıların taciz edilmemeleri ve zulme uğramamaları sağlanmıştır. ${ }^{48}$

Alaycı insan bencilliğinin, isteklerinin önünü kesmeye çalışan her şeye büyük bir öfkeyle bakar. Onlara karşı büyük bir nefret duyar. İnsan, tüm bu şeyleri düşman edinir ve onları yok etmek için elinden geleni yapar. İnsanın tek istediği olabildiğince hazza ulaşmak ve hazzın her türünü tatmak ve her şeye sahip olmaktır. Ancak bunun imkânsız olduğunu bildiği için, yolunu her şeye hükmetmek şeklinde değiştirir. İnsanın düsturu şu sözden ibarettir: "Her şey benim içindir. Başkaları için olan bir şey yoktur". ${ }^{49}$

Bir toplum zalim vasfını kazandığında, o toplum için yok oluş sürecinin başlaması Allah'ın iradesi gereğidir. Rad suresi 11 ayette "Allah bir topluluğun kötülüğünü isteyince artık onun önüne geçilmez". Yok olma sürecindeki bir toplum bütün uyarılara rağmen ahlaksızlıkta ve inkarda ısrarlı olmaları halinde, iş işten geçtikten sonra hatalarını anlarlar. Ancak bu fark ediş kendilerini kurtarmaya yetmemektedir. "Peygamberleri onlara apaçık deliller getirince, sahip oldukları bilgi ile şımardılar ve onları alaya aldılar. Sonunda alaya almakta oldukları şey kendilerini sarıverdi. Azabımızı gördükleri zaman, "Yalnız Allah'a inandık; O'na ortak koşmakta olduğumuz şeyleri inkâr ettik" dediler. Fakat azabımızı gördükleri zaman inanmaları, kendilerine fayda vermedi. Bu, Allah'ın kulları hakkında eskiden beri yürürlükte olan kanunudur. İşte orada inkârcılar hüsrana uğradılar." 50

Yüce Allah, Âd, Semûd ve Firavun kavimlerinin zulmedip yeryüzünde fesat çıkardıklarından dolayı helâk olduklarını bildirmektedir: "Bunlar şehirlerde azgınlık eden ve oralarda pek çok bozgunculuk çıkaran kimselerdi. Bu yüzden Rabbin onların üzerine azap kamçısı yağdırdı. Şüphesiz Rabbin, gözetlemededir."51 Ayetlerde anlatılan kavimler kaçınılmaz kötü sonuca adım adım yaklaşmışlardı. Yüce Allah bu insanlara bol servet, güç ve kuvvet vermişti. Fakat onlar ellerindeki imkânları halkların refah ve mutluluğu için değil, güçsüz insanlara baskı uygulamak, onları köleleştirip sömürmek için kullandılar. İnsanın doğasını bozacak ve onu saygınlıktan uzaklaştıracak eylemlerde bulundular. Nihâyetinde kendilerine gelen Allah'ın elçilerine karşı çıktılar. Onlara inanmamakla ve öğütlerine kulak vermemekle yetinmeyip haddi aşarak onlarla alay edip rencide ettiler. İşte bütün bunlardan dolayı ilâhî sünnet gereği azaba uğradılar.

\footnotetext{
48 Locke, Hoşgörü Üstüne Bir Mektup, s. 61-62.

49 Schopenhauer, Merhamet, s. 64.

$50 \quad$ Mü' $\min 40 / 83-85$.

$51 \quad$ Fecr $89 / 11-14$.
}

$\begin{array}{ccc}\text { Kelâm Araştırmaları Dergisi } & \text { C.: 14, } & \text { S.: } 1 \\ \text { Journal of Kalâm Researches } & \text { V.: 14, } & \text { I.: } 1 \\ \text { [KADER-e-ISSN: 1309-2030] } & 2016\end{array}$


Allah Teâla, peygamberleri alaya alanları sadece alay ettikleri için cezalandırmamaktadır. "Eğer Allah, insanları zulümleri yüzünden hemen cezalandırsaydı, yeryüzünde hiçbir canlı bırakmazdı. Fakat onları belirli bir süreye kadar erteler. Ecelleri geldiği zaman ise ne bir an geri kalabilirler, ne de öne geçebilirler." 52 Yüce Allah dini değerleri alaya alan insanları inkârcılıkta ileri gittikleri için farklı şekillerde cezalandırmıştır. "Bunların her birini kendi günahları yüzünden yakaladık. Onlardan taş yağmuruna tuttuklarımız var. Onlardan o korkunç sesin yakaladığı kimseler var. Onlardan yerin dibine geçirdiklerimiz var. Onlardan suda boğduklarımız var. Allah, onlara zulmediyor değildi, fakat onlar kendilerine zulmediyorlardı." ${ }^{53}$ Allah'ın günahkârları isyanları sebebiyle cezalandırması adaleti gereğidir. ${ }^{54}$

\section{Hz. Peygamber Dönemi İstihza}

Hz. Peygamber, peygamberler ailesinin bir üyesidir. ${ }^{55} \mathrm{~Hz}$. Peygamber de önceki peygamberler gibi kavmi tarafından alaya alınmıştır. Aslında inanmayanlarca alaya alınan hususlar tevhit ve ahiret (yeniden diriliş) konularıdır. Bizzat peygamberin şahsı değildir. O, vahiy öncesi bir takım kurullara müşriklerce üye yapılmış, Muhammed-ü'l-Emin olarak sıfatlandırılmıştır. Vahiy sonrası ise kâhin ve mecnun ${ }^{56}$ gibi aşağılayıcı yaftalamalara maruz kalmıştır. Hâlbuki her peygamber gibi $\mathrm{Hz}$. Peygamberin bizzat kendisi büyük bir ayettir. ${ }^{57}$ Gönderildiği toplumda Hz. Peygamberi ve kendisine tabi olanları alaya alan, küçümseyen insanların müşrik, münafık ve ehli kitap olduklarını görmekteyiz.

\section{a) İstihzayı açıkça yapanlar: Müșrikler}

Yüce Allah Hz Peygamber'i daha önceden ataları uyarılmamış ${ }^{58}$ Mekkelilere göndererek insanlığa fiilen son kez müdahale etmiştir. Hz. Peygamber ilahi mesajı iletmeye en yakınlarından başlamıştır. ${ }^{59} \mathrm{O}$ belli bir güce ve sayıya ulaşıncaya kadar Mekkelilerin açık aşağılaması ve alayı ile karşı karşıya kalmıştır. Mekkeliler daha ileri giderek elçinin hayatına son vermeyi bile göze almışlardır. ${ }^{60}$

\footnotetext{
$52 \quad$ Nahl 16/61.

53 Ankebut 29/40.

54 Aliyyü'l-Kari, Er-Ravdu'l-Ezher Fi Şerhi'l-Fıkhi'l-Ekber, haz. Şeyh Vehbî Süleyman Gavcî, (Beyrut: Daru'l-Beşairi'l-İslamiyye, 1998), s. 291.

55 Zemahşeri, el-Keşşaf, I-II, 732.

56 “(Ey Muhammed!) O hâlde, sen öğüt ver. Rabbinin nimeti sayesinde, sen ne bir kâhinsin, ne de bir deli." Tur 52/29.

Maturidi, Te'vilât, IV, 21.

Yasin 36/6.

Şuara 26/214; Müddessir 74/2.

Hani kâfirler seni tutuklamak veya öldürmek, ya da (Mekke'den) çıkarmak için tuzak kuruyorlardı. Onlar tuzak kuruyorlar. Allah da tuzak kuruyordu. Allah, tuzak kuranların en hayırlısıdır. Enfal 8/30.
}

\begin{tabular}{|c|c|c|}
\hline 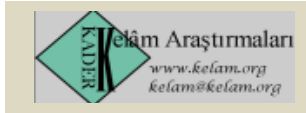 & $\begin{array}{l}\text { Kelâm Araştırmaları Dergisi } \\
\text { Journal of Kalâm Researches } \\
\text { [KADER-e-ISSN: 1309-2030] }\end{array}$ & 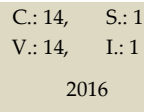 \\
\hline
\end{tabular}


Tebliğ görevinin başladığı Mekke'de dini alaya alanlar müşriklerdir. Özellikle Mekke'de nazil olan ayetlerin bir kısminda Hz. Peygamberin o günkü muhatapları arasındaki müşriklerin ${ }^{61}$ dini alaya almalarından bahsedilmektedir. Bazı ayetlerde ise müşriklere ibret, Hz. Peygamber ve müminlere teselli olarak önceki kavimlerdeki veya ahiretteki ${ }^{62}$ durumları açısından inkârcıların dini alaya almaları yer almaktadır. "Ey Muhammed! Andolsun, senden önce de birçok peygamber alaya alınmıştı da onlarla alay edenleri, alay ettikleri şey kuşatıp mahvetmişti. De ki: "Yeryüzünde gezin dolaşın da Peygamberleri yalanlayanların sonu nasıl olmuş bir görün." ${ }^{63} \mathrm{Bu}$ ayet bir yandan Hz. Muhammed'i, başına gelen sıkıntılardan dolayı teselli ederken, diğer yandan onu yalanlayanlara seslenerek bu eylemlere devam ettikleri takdirde, öncekiler nasıl yok olup gitmişlerse, aynı şekilde kendilerinin de helâk olacaklarını hatırlatmaktadır. Yüce Allah, Hz. Muhammed'e müşriklerin kendisiyle alay edip yalanlamalarından dolayı üzülmemesini ve tevhit inancını tebliğ etmeye devam etmesini istemektedir. Çünkü karşıtları kendisiyle alay etmeye ve onu yalanlamaya devam ettikleri takdirde, aynı yolu izleyen seleflerin başına gelen felâketler onların da başlarına gelecek ve yok olup gideceklerdir. ${ }^{64}$

Önceki kavimler gibi Mekkeli müşrikler de İslam dininin yayılmasını engellemek için ayn yöntemi kullanmışlardır. Hz. Peygamber'in ve inananların kişiliklerini, inanç ve değerlerini, ibadet ve yaşayışlarını dillerine dolayarak alaya almışlardır. "İnkâr edenlere dünya hayatı süslü gösterildi. Onlar iman edenlerle alay etmektedirler. Allah'a karşı gelmekten sakınanlar ise, kıyamet günü bunların üstündedir. Allah, dilediğine hesapsız rızık verir." 65

Kur'an, önceki peygamberleri yalayan toplumların düştükleri hatalarını, Hz. Muhammed'i yalanlayan Mekkelilere örnek olması için şöyle ifâde etmektedir: "Hayır öyle değil. Onlar, ilmini kavrayamadıkları ve kendilerine yorumu gelmemiş olan bir şeyi yalanladılar. Kendilerinden öncekiler de peygamberleri ve onlara indirilen kitapları böyle yalanlamışlardı. Bak, o zalimlerin sonu nasıl oldu." ${ }^{66}$

Hz. Muhammed'i yalanlayan müşrikler ile önceki peygamberleri yalanlayan insanlar iddialarında hiçbir delile dayanmamışlardır. Hâlbuki insan, dünya ve ahiret hayatını ilgilendiren önemli bir konuda karar verirken zanna ve nefsi arzulara değil, sağlam delillere göre hareket etse gerektir. Ancak müşrikler, Kur'an ayetlerinin ne dediğini hiç dinlemeden ve onları anlamak

61 En'âm 6/5; Hûd 11/8; Hicr 15/95; Enbiyâ 21/36; Şuarâ 26/6; Lokmân 31/6; Câsiye 45/9. Bkz. Maturidi, Te'vilât, VI, 369.

62 Kehf 18/106; Zümer 39/48; Câsiye 45/33, 35.

63 En'am 6/10-11. Ayrıca bkz. Hicr 15/11; Nahl 16/34; Kehf 18/56; Enbiyâ 21/41; Furkân $25 / 41$.

64 Taberi, Camiu'l-Beyan, IX, 165-166; Yazır, Hak Dini, III, 1883

65 Bakara 2/212; Bkz. Maide 5/57-58; Saffat 37/12-14.

66 Yunus 10/39.

\begin{tabular}{|ccc} 
Kelâm Araştırmaları Dergisi & C.: 14, & S.: 1 \\
Journal of Kalâm Researches & V.: 14, & I.: 1 \\
[KADER-e-ISSN: 1309-2030] & 2016
\end{tabular}


için gayret sarf etmeden inkâr etmişlerdir. Çünkü onlar atalarının dinine aykırı her türlü düşünceyi daha ilk başta inkâr etmeye şartlanmışlardı. Taklit bataklığına kapılıp akıllarını işlevsiz hale getiren müşrikler, apaçık hakikati kabul edebilecek güçten yoksun hale gelmişlerdi. Onlardan önceki inkârcılar da peygamberlerin getirdikleri mucizelerin doğruluğu konusunda hiç düşünmeden atalarının izini takip edip inat etmeye devam etmişlerdi. Böyle bir insan tipi, kendi kararlarının izini sürmek yerine, onların zayıf olduğunu düşünerek başka dallara tutunan insan tipidir. Bu kişiler, sadece atalarınca tecrübe edilmiş ya da başka insanların tecrübe etmiş olduğu düşüncelerin ardından gitmektedirler. ${ }^{67}$

Yüce Allah, Yunus suresinin 39 ayetinin sonunda "Bak, o zalimlerin sonu nice oldu" demekle Hz. Muhammed'e seslenerek; kendilerine gönderilen peygamberleri yalanlayan, alaya alan kavimlerin kasırga, yerin dibine batırılma, suda boğulma gibi cezalarla yok edildikleri gibi, kavminin de kendisini yalanlamaya devam etmeleri halinde benzeri felâketlerle cezalandırılacaklarını bildirmektedir. ${ }^{68}$

Allah Teâla Mekke döneminde elçisinden dinle ve vahiyle alay edildiğine şahit olduğunda bulunduğu ortamı terk etmesini emretmiştir. Hz. Peygamber de alay edenler başka bir söze geçinceye kadar onların konuşmalarına eşlik etmemiştir. Bunun sebebi yaşanılan çevrenin insanın dini hayatı üzerindeki öneminin büyük olmasıdır. Kur'an-1 Kerim'de Allah'ın mesajının inkâr edildiği, hafife alındığı ortamlarda müminlerin bulunmamaları emredilmektedir. ${ }^{69}$ Aynı ortamı paylaşmayı yasaklayan ayetin devamında, Müslümanlar verilen emre uymaz ve bu tür meclislerde bulunurlarsa "kesinlikle onlar gibi olacakları" ikazı yapılmaktadır. ${ }^{70}$

Hz. Peygamber, alay edenlerin alaylarına aldırış etmemiş ve kendisine verilen tebliğ görevini en güzel şekilde ve eksiksiz bir şekilde yerine getirmeye çalışmıştır. Müşrikler, Hz. Peygamber'in bu görevi yapmasından rahatsız olmakta ve onunla alay ederek ve onun hakkında gerçek dışı iddialar ortaya koyarak engel olmaya çalışmaktaydılar. Müşriklerin bu davranışları karşısında Hz. Peygamber üzülmekte ve incinmekteydi. İşte

67 Schopenhauer, Merhamet, s. 47. Bkz. Bakara 2/170; Maide 5/104;

68 Taberi, Camiu'l-Beyan, XII, 184.

69 Bkz. Nisa 4/140; “Ayetlerimiz hakkında dedikoduya dalanları gördüğün vakit başka bir söze dalıncaya kadar onlardan yüz çevir, uzaklaş. Şayet şeytan sana unutturursa hatırladıktan sonra (kalk), o zalimler grubu ile beraber oturma". En'am 6/68.

70 Muhammed Abduh'a göre bu ayet, her zaman ve zemindeki müminlere hitap etmektedir. Ona göre ayet: "Ey müminler, ister Peygamberi ve dinini yalanlayan kâfirlerden olsun isterse tefrika çıkartmak isteyen hevâ ehlinden olsun bizim ayetlerimizle ilgili ileri geri konuşanları, güç göstermek için kavga çıkaranları ve alay edenleri terk edin. Onlar bu kötü işlerinden vazgeçinceye kadar onlardan yüz çevirin ve onlara sırtınızı dönün" emrini beyan etmektedir. Muhammed Abduh, Tefsirü̈l-Menar: Tefsiru'l-Kur'an'il-Azim, haz. Muhammed Reşid Rıza, (Kahire: Daru'l-Menar, 1947), VII, 505-506.

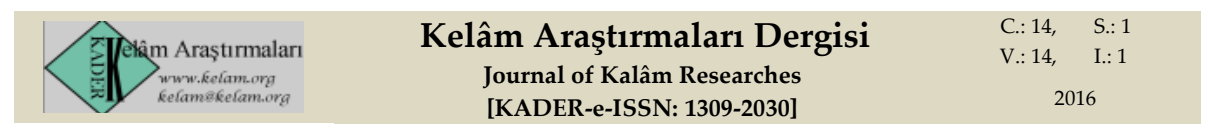


böyle bir durumda "Şüphesiz O alay edenlere karşı Biz sana yeteriz."71 buyurularak, Hz. Peygamber'e Yüce Allah'ın güvencesi altında olduğu bildirilmektedir. Ayrıca alay edenlere karşılık vermesi gerekmediği, en güzel karşılığın Allah tarafından verileceği belirtilmiştir. Hz. Peygamberin göğsü müşriklerin Allah'ın ayetlerine icabet etmemeleri ve dilleri ile kendisine eza vermeleri sebebiyle daralmaktadır. ${ }^{72}$ Ardından teselli etmeye devam edilerek "Andolsun, onların söyledikleri şeylerden dolayı göğsünün daraldığını biliyoruz."73 ayetiyle, kendinden ve içinde bulunduğu durumdan haberdar olunduğu ifade edilmiştir. ${ }^{74}$

Yüce Allah peygamberinin göğsünün daralmasına ve inkârcıların alay etmelerine karşı peygamberine metot öğretmektedir.75 Öncelikli olarak Rabbini hamd ederek tüm noksanlıklardan tenzih etmesi ve secde edenlerden olmasını istemektedir. ${ }^{76}$ İkinci olarak kendisine düşenin sadece tebliğ olduğu vurgulanmaktadır.77 Üçüncü olarak şayet insanlar çağrıya sırtlarını dönerlerse, onların bekçisi olmadığını bilmesi gerektiğini hatırlatmaktadır. ${ }^{78}$

\section{b) İstihzayı gizli şekilde yapanlar: Münafıklar}

Hz. Peygamber Medine'ye geldiği sırada Müslüman ve Müşrik Araplarla, Ehl-i kitap olan Yahudilerle, az sayıda Hıristiyanlarla karşılaştı. Ancak Hz. Peygamberin kısa sürede Medine'de devlet reisliği pozisyonunu elde etmesi Müslüman gibi gözüken bir grubun oluşmasına sebep olmuştur. ${ }^{79}$ Dolayısıyla bu topluluğun oluşmasındaki en önemli etken Hz. Peygamberin Medine'de kazandığı siyasi nüfuz ve siyasi hâkimiyettir.

İkiyüzlülügün baş silahı olan nifak, Müslümanların güçsüz oldukları Mekke'de değil, Medine'de etkili olmaya başlamıştır. Kur'an-1 Kerim'de münafıkların imandan çok küfre yakın oldukları80, müminlerle karşılaştıklarında inandıklarını söyleyip, taraftarlarıyla bir araya

Hicr 15/95.

Maturidi, Te'vilât, VI, 469.

Hicr 15/97.

Maturidi, Te'vilât, VI, 469.

Zemahşeri, el-Keşşaf, I-II, 599.

Hicr 15/98. “Şirk kelimeleri, Kur'an'a dil uzatılması, peygamberlikle alay edilmesi, şüphesiz canını sıkar bunalırsın. Sıkıldığın zaman hemen Rabbine hamdederek O'nu tesih et ve O'nu ulula, için açllır." Yazır, Hak Dini, V, 3079

77 Mâide 5/92, 99; Nahl 16/35, 82; Nûr 24/54; Ankebût 29/18; Teğabun 64/12.

78 "Eğer yüz çevirirlerse, bilesin ki biz seni onların üzerine bekçi göndermedik. Sana düşen sadece duyurmaktır. Biz insana katımızdan bir rahmet tattırdığımız zaman ona sevinir. Ama elleriyle yaptıkları yüzünden başlarına bir kötülük gelirse, işte o zaman insan pek nankördür!" Şura 42/48.

79 Izutsu, Toshihiko, Kur'an'da Dini ve Ahlâkî Kavramlar, çev. Selâhattin Ayaz, (İstanbul: ts.), s. 244. "İnsanlardan, inanmadıkları hâlde, "Allah'a ve ahiret gününe inandık" diyenler de vardır. Bunlar Allah'1 ve mü'minleri aldatmaya çalışırlar. Oysa sadece kendilerini aldatırlar da farkında değillerdir." Bakara 2/8-9. 
geldiklerinde ise müminlerle alay ettiklerini söyledikleri, dine olan bağl1lıklarının dünyevi menfaatlere göre değiştiği bildirilmektedir. ${ }^{81}$

Münafıkların gerçek niyetleri ancak kendi meclislerinde ve kendi dostları arasında ortaya çıkmaktadır. Bu hallerini de alaycı bir tavırla birbirlerine anlatmaktadırlar. Kur'an bu hususa şu şekilde temas etmektedir: "İman edenlerle karşılaştıkları zaman, "İnandık" derler. Fakat şeytanlarıyla (münafık dostlarıyla) yalnız kaldıkları zaman, "Şüphesiz, biz sizinle beraberiz. Biz ancak onlarla alay ediyoruz" derler. Gerçekte Allah onlarla alay eder (alaylarından dolayı onları cezalandırır); azgınlıkları içinde bocalayıp dururlarken onlara mühlet verir." 82

Münafıklar sadakat arz ederken hainliklerini, cesaret arz ederken korkaklıklarını sergilemektedirler. Abdullah b. Übeyy, Ebu Bekir, Ömer, Ali başta olmak üzere Müslümanları aşırı şekilde övmektedir. İnananların meclisinden ayrılıp gerçek dostlarının yanına geldiğinde ise onları alaya aldığını arkadaşlarına söylemektedir. ${ }^{83}$ Şayet insanlar toplantılarında fitne fesat işlerine girişiyorlarsa, onları buna dini değil, dindirmek için istekli oldukları ıstırapları ve çileleri teşvik etmektedir. İkiyüzlü insanları fesat için bir araya getiren tek bir şey vardır, o da zulümdür. ${ }^{84}$

Hz. Peygamber ayırım yapmadan herkesin sorunlarını dinlediği gibi münafıkların da sorunlarını dinlemektedir. Onların görünen imanlarına itibar etmektedir. Münafıklar ise peygamberi incitip: "O her söyleneni dinleyen bir kulaktır" diyerek onunla alay etmektedirler. Hz. Peygamber ise onların gerçekte iman etmedikleri sırlarını açığa çıkarmamakta ve kusurlarını gizlemektedir. Yüce Allah elçisinin hayırlı biri olduğunu şu şekilde zikretmektedir: “De ki: “O, sizin için bir hayır kulağıdır ki Allah'a inanır, mü'minlere inanır (güvenir). İçinizden inanan kimseler için bir rahmettir. Allah'ın Resulünü incitenler için ise elem dolu bir azap vardır." ${ }^{85}$

Müşrikler: "Bizler her hangi bir konu hakkında dilediğimiz bir şeyi söylüyoruz. Sonra da ilk sözümüzden farklı bir şey söylüyoruz. Ardında da Peygamberden özür diliyoruz. $\mathrm{O}$ da bizi tasdik edip özrümüzü kabul ediyor" diyerek münafıklara Hz. Peygamber'i hafife almak için böyle yapmalarını tavsiye etmektedirler. Münafıklar da Hz. Peygamberi her şeyi dinleyen bir kulak olarak değerlendirmişlerdir. Münafıklarca $\mathrm{Hz}$. Peygamber'in 'kulak' olarak nitelendirilmesi yaptığı hatadan dolayı özür dileyenin özrünü kabul etmesi ve onu dinlemesi sebebiyledir. Halbuki Hz.

Hacc 22/11; Bakara 2/14.

Bakara 2/14-15.

Yazır, Hak Dini, I, 237-238.

Locke, Hoşgörü Üstüne Bir Mektup, s.73-74.

Tevbe 9/61; Zemahşeri, el-Keşşaf, I-II, 450.

\begin{tabular}{|c|c|c|}
\hline द्री elâm Araștrmaları & $\begin{array}{l}\text { Kelâm Araştırmaları Dergisi } \\
\text { Journal of Kalâm Researches } \\
\text { [KADER-e-ISSN: 1309-2030] }\end{array}$ & $\begin{array}{c}\text { C.: } 14, \quad \text { S.: } 1 \\
\begin{array}{c}\text { V.: } 14, \quad \text { I.: } 1 \\
2016\end{array}\end{array}$ \\
\hline
\end{tabular}


Peygamber kişinin özrü olsun veya olmasın keremi, şerefi ve ahlakının güzelliği sebebiyle böyle yapmaktadır. ${ }^{86}$

İnanmadığı halde inanan insanların arasına gizlenerek inanmış gibi gözükenler bu hallerinden son derece memnundurlar. Tek bir şeyden endişe duymaktadırlar. O da içlerinde saklamakta oldukları sırlarının açığa çıkması olsa gerektir. Kur'an onların bu psikolojilerini Tevbe suresinin 64 ayetinde şu şekilde gün yüzüne çıkarmaktadır: "Münafıklar, kalplerinde olan şeyleri, yüzlerine karşı açıkça haber verecek bir sürenin üzerlerine indirilmesinden çekinirler." Unutulmamalıdır ki hiç kimsenin iyi niyeti, bilinçaltına kötü niyetinden önce varamaz. ${ }^{87}$

Münafıklar, ortak yapılan eylemlerde Allah'ın elçisine ve inananlara yardımcı olacakları yerde inananların yapmakta olduğu işlere alaycı tavırlarıyla engel olmaya çalışmaktadırlar. Bu tavırlarıyla Müslümanlar arasında moral bozukluğuna sebep olmaktadırlar. Hz. Peygamber Tebük seferine çıkarken münafıklardan bir grup da önde gitmekte ve kendi aralarında Kur'an'la Elçiyle alay etmekteydiler. "Şu adama bakın, Şam kalelerini fethetmek istiyor heyhat, heyhat..." diyorlardı. Hz. Peygamber onların bu tavırlarından haberdar edilince hemen sözlerinden çark ediyorlar. ${ }^{88}$ "De ki: "Siz alay ede durun! Allah, çekindiğiniz o şeyi ortaya çıkaracaktır." Şayet kendilerine niçin alay ettiklerini sorsan, "Biz sadece lâfa dalmıştık ve aramızda eğleniyorduk", derler. De ki: "Allah'la, O'nun ayetleriyle ve peygamberiyle mi eğleniyordunuz?"

Maturidi, Tevbe suresi 65 ayette geçen اباسّ “Allah'la mı alay ediyorsunuz?" ifadesini şu şekilde izah etmektedir: "Müminlerin zatına izafet ihtimali vardır. Çünkü hiç kimsenin Allah ile alay etme kastı yoktur ve olamaz. Bu ayette münafıklar Allah'ın elçisi ve müminlerle alay etmektedirler. Allah ise bu alay işini kendisine izafe etmiştir. Bunun örnekleri Bakara suresi 9 ayette "Allah'ı aldatmaya çalışırlar", Muhammed suresi 7 ayette ise 'eğer siz Allah'a yardım ederseniz' şeklinde yer almaktadır. Yüce Allah bu yöntemi inananları yüceltmek ve onlara ikramda bulunmak ${ }^{89}$ için kullansa gerektir.

Bir suçun cezası, kendi cinsiyle karşılık bulmasıdır. Allah da alay edenleri istihza cezasıyla cezalandırır. ${ }^{90}$ Benzer durumlar Kur'an'ın farklı surelerinde yer almaktadır. Nisa suresinin 142 ayetinde; "Münafıklar, Allah'ı aldatmaya çalışırlar. Allah onları aldatır." Aldatanların cezası aldatılmadır. Al-i İmran suresinin 54 ayetinde; “Onlar Allah'a tuzak kurdular. Allah da onlara tuzak kurdu." İnsanlar hangi ırktan, renkten, milletten olursa olsunlar Yüce Allah tarafından yaratılmışlardır. Yaratılış anlamında birbirlerine üstünlükleri yoktur. Şekil ve benzerlikte birbirlerinin aynıdır. Yaratılmış bir varlık olan

Maturidi, Te'vilât, V, 411.

Schopenhauer, Merhamet, s. 88.

Zemahşeri, el-Keş̧af, I-II, 451; Maturidi, Te'vilât, V, 419; Yazır, Hak Dini, IV, 2587.

Maturidi, Te'vilât, V, 420.

Maturidi, Te'vilât, I, 386-387.

\begin{tabular}{|c|c|c|}
\hline 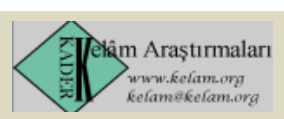 & $\begin{array}{l}\text { Kelâm Araştırmaları Dergisi } \\
\text { Journal of Kalâm Researches } \\
\text { [KADER-e-ISSN: 1309-2030] }\end{array}$ & $\begin{array}{c}\text { C.: } 14, \quad \text { S.: } 1 \\
\begin{array}{c}\text { V.: } 14, \quad \text { I.: } 1 \\
2016\end{array}\end{array}$ \\
\hline
\end{tabular}


insanın kendisi gibi birini alaya alması onunla eğlenmesi uygun olmasa gerektir. Alay etmenin Allah'a izafe edilmesi ise caizdir. Çünkü Allah'ın şekil ve benzeri yoktur. Aynı şekilde "Kibir" de Allah için uygunken insan için uygun değildir. ${ }^{91}$

İbn Teymiyye, “Müslümanlar güçlü olduklarında Hz. Peygamber'i üzen sözler söyleyen münafıkları öldürmek caizdir. Hz. Peygamber, bulundukları toplumda zayıf olduklarında ise insanların İslam'dan nefret edebileceklerinden korktuğu için münafıkları öldürtmeyi terk etmiştir." ${ }^{22}$ demektedir. Bu anlayış Kur'an'ın "Sen af yolunu tut, iyiliği emret, cahillerden yüz çevir." ayetiyle ve Hz. Peygamber'in merhamet anlayışıyla çelişmektedir.

Yazır, müslümanların münafıklara karşı sergileyecekleri tavrı şu şekilde izah etmektedir: Kutsal değerler ile alay eden münafıklara dünyada Müslüman muamelesi yapılır. Dine mahsus hükümlerde serbest değildirler. Münafıklara, gerek ibadet gerekse muamelelerle ilgili dini hükümlerin hepsi Müslümanlar gibi tatbik edilir. Bunda üç hikmet vardır. Birincisi, İslamın sabır ve huzuru, terbiyesinin yüksekliği, ruhî hoşgörüsüdür. İkincisi bu sayede onların İslam beldesinde ve İslamî hükümler altında yetişecek olan çocuklarından ciddi müminlerin yetişmesine imkân sağlamaktır. Üçüncüsü ise münafıkların kalben iman etmedikleri ilahi hükümlerin uygulamasına baskı yapmadan zorlamak suretiyle her an gönül azabı içinde bırakmak ve alaycilıklarının cezasını dünyada çektirmektir." 93

Medine'de Hz. Peygamberi ve Müslümanları alaya alan, onlara hakaret edip kötü söz söyleyen Yahudiler de olmuştur. Bunlardan birisi de Kâb b. Eşref'tir. O, Beni Nadir Kabilesinin ileri gelenlerinden ve güçlü bir şairdi. Hz. Peygamber'in barış ortamındaki kazanımlarından rahatsızlık duymaktaydı. Bunun için fitne çıkarmaya çalışmaktaydı. Müslümanlara olan kinini ve nefretini her firsatta dile getirmekte onlara eziyet etmekten geri durmamaktaydı. Medine'den ayrılıp Mekke'ye varınca Hz. Peygamber'e olan düşmanlığını açıkça ilan etti. Ehli Kitap olmasına rağmen müşrikleri üstün tutup onların isteğiyle putlarına secde etti. ${ }^{94}$

Kâb, müşrikleri Müslümanlarla savaş yapmaya ikna etti. Mekkelilerin desteğiyle Medine'de Müslümanlara zarar vermeye onları incitmeye

91 Maturidi, Te'vilât, I, 387, 490. Allah'ın alay etmesi İlahi adalettir. Yazır, Hak Dini, I, 242.

92 İbn Teymiyye, Takribü Sarim'il-Meslul Alâ Şatimi'r-Rasul, haz. Dr. Salih Es-Savi, (y.y.: Daru'l-i'llami'd-Düveli, 1995), s. 64.

93 Yazır, Hak Dini, I, 240-241. Hz. Peygamber münafıklara karşı hiç kimsenin tahammül edemeyeceği şekilde sabırlı, müsamahalı ve ihtiyatlı davranmıştır. Bu strateji sayesinde onların müşrikler safına geçmesini önleyerek birliği korumuş ve bir topluluk oluşturup teşkilatlanmalarını da engellemiştir.

94 “Kendilerine Kitap'tan bir nasip verilmiş olanları görmüyor musun? Onlar "cibt"e ve "tâğût"a inaniyorlar. İnkâr edenler için de, "Bunlar, iman edenlerden daha doğru yoldadır" diyorlar." Nisa 4/51.

\begin{tabular}{|c|c|c|}
\hline 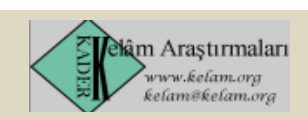 & $\begin{array}{l}\text { Kelâm Araştırmaları Dergisi } \\
\text { Journal of Kalâm Researches } \\
\text { [KADER-e-ISSN: 1309-2030] }\end{array}$ & $\begin{array}{l}\text { C.: } 14, \quad \text { S.: } 1 \\
\begin{array}{l}\text { V.: } 14, \quad \text { I.: } 1 \\
2016\end{array}\end{array}$ \\
\hline
\end{tabular}


şiirleriyle Müslüman hanımlara iftiralar atmaya başladı. ${ }^{95} \mathrm{~Hz}$. Peygamber'i ve Müslümanları en ağır şekilde aşağılıyordu. Müşriklerin Müslümanlara karşı kin ve nefretini artıracak, intikam hislerini coşturacak şiirler okumaya ve Bedir'de ölen şirkin önderleri için ağıtlar yakıp ağlamaya başladı. ${ }^{96}$

Hz. Peygamber'in Kâb’a karşı olan tavrı çok farklıdır. O, "Kitap ehlinden birçoğu, hak kendilerine belirdikten sonra dahi, içlerindeki kıskançlıktan ötürü sizi, imanınızdan sonra küfre döndürmek isterler. Siz şimdilik, Allah onlar hakkındaki emrini getirinceye kadar affedin, hoşgörün. Şüphesiz Allah, gücü her şeye hakkıyla yetendir." "97 ayeti gereğince Kâb'ın yaptıklarına sabretmiştir. Fakat anlaşmayı bozup düşmanlığını açığa vurarak yaptıkları devletin güvenliğine zarar verince yerel kanunlara göre cezalandırılmıştır.

Kâb'ın öldürülmesi olayı, Vakidi'nin dediği gibi Hz. Peygamber'in kendisinin onun eziyetinden kurtarılması yahut İbn Sad'ın iddia ettiği gibi Hz. Peygamber'i ve inananları alaya alan şair olması ${ }^{98}$ sebebiyle gerçekleşmemiştir. Ka' $\mathrm{b}^{\prime}$ ın Medine'ye dönüşünden sonraki hıyanet girişimi, Müslümanlardan oluşmuş olan bir birliğin kılıçları altında hayatını kaybetmesiyle son bulmuştur. ${ }^{99}$ Elçinin ve inananların hissettiği acının bir benzerini kendilerine eziyet eden kişinin de hissettiğini bilmek Müslümanlarda bir rahatlama ve sevinç hissi meydana getirdiğ $i^{100}$ açıktır.

Hz. Peygamber'e hakaret eden bir diğer Yahudi ise kadındır. "Yahudi kadın Peygamber'e kötü söz sarfetti ve onun giybetini yaptı. Âmâ olan Müslüman adam kadın ölünceye kadar onu boğdu. Allah Resulü kadının kanını helal sayd." ${ }^{101}$ İbn Teymiyye bu hadisi peygambere hakaret edenlerin öldürüleceğine ${ }^{102}$ delil getirmektedir.

Halbuki Yahudi kadın âmâ adamı dinine bakmaksızın sırf engelli olduğu için evine almıştır. Ona yemek vermiş ve ona iyi davranmıştır. Kadın, Peygamber hakkında kötü konuşarak ona eziyet etmeyi sürdürünce âmâ tarafından öldürülmüştür. Âmâ kişi 'sabretmek gibi büyük bir işi' 103 yerine getirememiş, tahrike kapılmaya engel olamamıştır. Öldürme işi Hz. Peygambere danışılmadan yapılmış, fiili durum sonradan ona tasdik

95 İbn Hişam, Ebû Muhammed Abdülmelik, es'Siretü'n-Nebeviyye, tahk. Mustafa es-Sakkâ, (Misır: ts.), II, 51; İbn Sa'd, Muhammed, et-Tabakâtü'l-Kübrâ, tahk. Dr. Ali Muhammed Ömer, (Kahire: Mektebetü'l-Hanci, 2001), II, 29.

96 İbn Hişam es'Sire, II, 51; Vâkıdî, Muhammed b. Ömer, Kitâbü'l-Meğââ̂, haz. M. Jones, (Beyrut: Âlemü'l-Kütüp, 1984), I, 183, İbn Sad, et-Tabakat, II, 29-30; Hamidullah, Muhammed, İslam Peygamberi, çev. Salih Tuğ, (Ankara: Yeni Şafak Yayını, 2003), I, 195.

97 Bakara 2/109.

98 Vâkıdî, el-Meğâzzî, I, 187; İbn Sad, et-Tabakat, II, 30.

99 Hamidullah, İslam Peygamberi, I, 196.

100 Schopenhauer, Merhamet, s.41.

101 Ebu Davud, Süleyman b. Eş'as; Kitabu's-Sünen, (Beyrut: Müessesetü'r-Reyyan, 1998), V, 66-67, Hadis No: 4362. Bkz. İbn Teymiyye, Takribü Sarim'il-Meslul, s.42.

102 İbn Teymiyye, Takribü Sarim'ül-Meslul, s.42-43.

103 Zemahşeri, el-Keşşaf, I-II, 206.

\begin{tabular}{|ccc} 
Kelâm Araştırmaları Dergisi & C.: 14, & S.: 1 \\
Journal of Kalâm Researches & V.: 14, & I.: 1 \\
[KADER-e-ISSN: 1309-2030] & 2016
\end{tabular}


ettirilmiştir. Bu uygulama kendisine sözleriyle eziyet eden, savaşlarda kendisine karşı savaşan Mekke'nin bütün müşrik kadınlarını fetih günü affeden peygamberin davranışına aykırı olsa gerektir.

Al-i İmran suresinin 186 ayetinde “... Sizden önce kendilerine kitap verilenlerden ve Allah'a ortak koşanlardan üzücü birçok söz işiteceksiniz. Eğer sabreder ve Allah'a karşı gelmekten sakınırsanız bilin ki, bunlar yapmaya değer azmi gerektiren işlerdendir" buyrularak inananların diğer inanç sahibi kişilerce hakarete ve sözlü sataşmalara maruz kalacağ bildirmektedir. Allah müminlerden, Ehli kitap veya müşriklerden gelecek tahriklere kapılmamalarını, alay etmelerine, kötü söz ve propagandalarına karşı sabırlı olmalarını, maddi ve manevi zarar veren her türlü kötü davranıştan sakınmalarını istemektedir. Müslümanlar gurura kapılan kötü ahlaklılar gibi olmamalıdırlar. ${ }^{104}$

Yüce Allah, Hz. Peygamber ve inananları toplumda güçlü olduklarında inanmayanların alay etmelerinde materyal olarak kullandıkları dinin aslından olmayıp müminlerde bulunan söz, tavır, davranış ne varsa onun değiştirilip veya ortadan kaldırılıp alaylarına mahal bırakmamaları için uyarılmışlardır: "Ey iman edenler! Siz kendinizi düzeltmeye bakın! Siz doğru yolda olduktan sonra sapanlar size zarar veremez."105 ayetinde belirtildiği gibi insanın ilk başta kendisini kötülüklerden arındırıp düzeltmesi gereği, kendisini düzelttiği müddetçe zararlardan korunmuş olacağı, bu hakikati destekleyen ilkelerdendir. Aynı zamanda bir müslümanın hayra davet etmesi ${ }^{106}$ ve hayırda yardımlaşmasi ${ }^{107}$ nasıl dinin emriyse, kötülükleri engellemesi ve onlara fırsat vermemesi ${ }^{108}$ ve bu hususta müminlerle yardımlaşması da dinin emridir.

Dini alaya alanlarla insani, ticari ve ekonomik ilişkiler hariç olmak üzere kalbî ve dostane tüm irtibatın kesilmesi gerektiğidir. Bu husus “Ey iman edenler! Ne dininizi alay ve eğlence konusu yapan sizden önce kendilerine kitap verilenleri, ne de diğer kâfirleri dost edinmeyin. Mü'min iseniz, Allah'ın bu buyruklarına karşı gelmekten sakının!"109 âyeti ile bildirilmiştir. Böylece dine yapılan alaylardan, onların menfi etkilerinden korunmuş olan müslümanların dine karşı alaycı tavır takınan insanların kötü etkilerinden tamamen kurtulmaları sağlanmaktadır. Hakiki Dost insanın cevap bulan ihtiyaçlarıdır. Dostluğu her daim zamanı diriltmek için aramak gerekir. Zira dostluğa düşen ihtiyaçları karşılamaktır, boşluğu doldurmak değildir. ${ }^{110}$

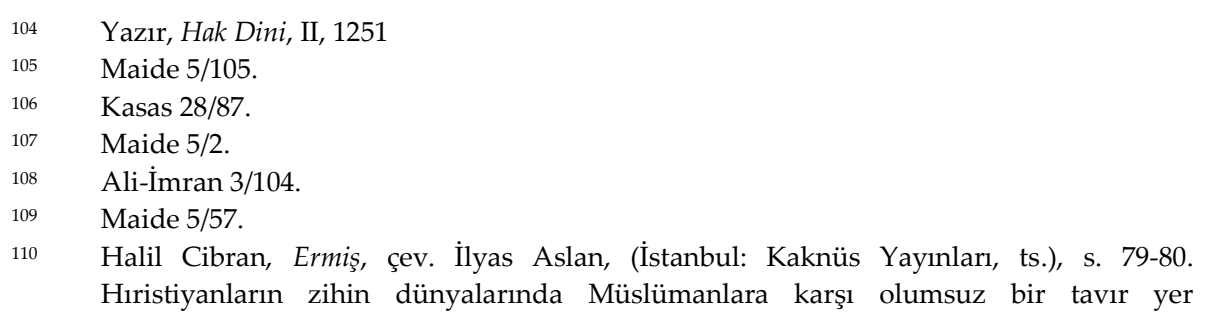

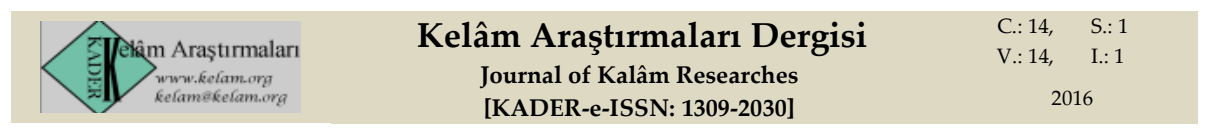


Bir insanın hatalı inanışlarının ve aykırı ibadet şekillerinin, başka bir insanın haklarını çiğnemek anlamına gelmediği görülürse veya cehennemlik oluşunun başka insanların işlerini etkilemediği düşünülürse, her insanın ruhunun kurtuluşunun sadece kendisini ilgilendirdiği ortaya çıkar. İnsanlar her çeşit baskı ve zorlamadan sakınmalıdır. Zorbaca hiçbir şey yapılmamalıdır. Hiç kimse ikna edilmediği sürece bir başkasının nasihatlerine ve ihtarlarına boyun eğmek zorunda ${ }^{111}$ olmasa gerektir. Bir de kötü insanların iyi olmasının çaresi, kafalarının aydınlatılması ve idraklerinin geliştirilmesinden ibarettir. İnsanın bu sayede daha nesnel ve daha doğru olan bir anlayışa kavuşma olasılığı artacaktır. ${ }^{112}$

\section{Müslümanların Birbirlerini İstihza Etmesi}

İslam'ın Mekke'ye tam manasıyla hâkim olmasıyla birlikte müşriklerde öldürülme korkusu meydana geldi. Bu korkunun kaynağı ise yıllardır elçiye ve Müslümanlara yaptıkları eziyet ve aşağılamadır. Hz. Peygamber Mekke'nin fethi günü İkrime b. Ebî Cehîl, Abdullah b. Sa'd b. Ebî Serh, Mikyes b. Subâbe, Huveyris b. Nukayz, Abdullah b. Hatal, Vahşî b. Harb, Safvân b. Ümeyye, Hebbâr b. Esved, Abdullah b. Zibarâ, Ka'b b. Züheyr, Hind b. Utbe, Amr b. Hişam'ın cariyesi Sâre, Fertenâ (Kureynâ), Ernebe (Kureybe), Erneb'nin öldürülmelerini emretti. ${ }^{113}$ Burada isimleri zikredilenler 'harp suçluları'dır. Hatta bu kişiler yürürlükte olan kanunlar bakımından da suçlu durumundaydılar. Bu sayılanlardan her hangi biri ne zaman ele geçirilirse, şayet İslama girdiğini ve işlediği suçlardan pişman olduğunu itiraf etmişse durum önce Hz. Peygamber'e bildirilmiş ve o da affa onay vermiştir. Bu konuda sadece üç idam vardır ki kendisine yeniden danışılmadan icra edilmiştir. ${ }^{114}$

Hz. Peygamber de diğer insanlar gibi bir insandı. Ancak Allah elçisi olarak getirdiği bir 'ilahi tebliğ' görevi vardı. Kendisinden sonra sonsuza kadar müminlerin davranış ve hareket tarzlarında genel bir ilke ve kural teşkil edecek bir tutum göstermek zorundaydı. Kötüye kötülükle karşılık veremezdi. Çünkü kötüye kötülükle karşılık veren intikam duygusu

almaktadır. Bunun örneğini Toynbee'nin annesi ile olan bir diyaloğunda görmekteyiz: "Haçlı seferlerinde Hıristiyanlar yenilince, "sanırım Hıristiyanlar Türkleri Anadolu'dan çıkartacak güçte değil" dedim. Annem ise "Hayır, o güce sahipler. İstedikleri takdirde onları herhangi bir zamanda oradan çıartabilirler. Hıristiyan ülkelerin bencilce birbirleriyle olan rekabetleri Türklerin layı olmadıkları yerde yaşamaya devam etmelerine sebep olmaktadır." diye cevap verdi." Toynbee, Hatıralar: Tanıdıklarım, s. 288.

$111 \quad$ Locke, Hoşgörü Üstüne Bir Mektup, s. 65.

112 Schopenhauer, Merhamet, s. 140. Eğitim sadece işlenmiş zekâlarla işlenmemişler arasında bir ayırım meydana getirmekle kalmaz; işlenmiş zekâlar arasındaki farkları da kültür oranında artırır. Rousseau, İnsanlar Arasındaki Eşitsizliğin Kaynağı, s. 128.

113 İbn Hişam, es-Sire, II, 410-411; İbn Sa'd, et-Tabakât, II, 126. Bu ismi geçenlerden beş tanesi öldürülmüştür. Onlar da Huveyris b. Nukayz, Abdullah b. Hatal, Sâre, Mikyes b. Subâbe el-Leysî, Ernebe (Kureybe)'dir. Bkz. İbn Hişam, es-Sire, II, 410-411; İbn Sa'd, etTabakât, II, 126; Vâkıdî, el-Meğâầ̂, II, 825.

114 Hamidullah, İslam Peygamberi, I, 269.

\begin{tabular}{|ccc} 
Kelâm Araştırmaları Dergisi & C.: 14, & S.: 1 \\
Journal of Kalâm Researches & V.: 14, & I.: 1 \\
[KADER-e-ISSN: 1309-2030] & 2016
\end{tabular}


anlamsızdır. Bazen geçmişteki bir şey için kişi karşısındakine acı çektirir. Oysa bunun olası bir getirisi yoktur. Tek amaç karşısındakine aynı acıyı tattırmaktır. Ortaya çıan durum ise karşısındakinin çektiği acıdan zevk almaktan öte hiçbir şey ifade etmemektedir. ${ }^{115}$

Hz. Peygamber'in intikam duygusuyla hareket etmediğini öldürülmesi emrini verdiği İkrime b. Ebi Cehil'i affetmesinde görmekteyiz. İkrime, Hz. Peygamberin Mekke'ye barış ve huzur içinde, hiçbir çatışma olmaksızın girişinde mücadele edip karşı çıkan tek kişiydi. Hz. Peygamberin affediciliğinden hiçbir ümit taşımaksızın kaçtı. Habeşistana sığınmak istedi. Genel affın çıkarılmasından sonra karısı, elçinin huzuruna çıktı ve ondan kocası için merhamet diledi. Hz. Peygamber hiçbir şüpheye kapılmaksızın bunu derhal kabul etti. İkrime'yi affetti. Karısı İkrime'yi Hz. Peygambere getirdi. O da Müslüman oldu. ${ }^{116}$

İslam dininin müntesibi olmayan insanlarla bu tür sorunlar yaşanırken, inananların da birbirlerini alaya aldıkları görülmektedir: "Ey iman edenler! Bir topluluk bir diğerini alaya almasın. Belki onlar kendilerinden daha iyidirler. Kadınlar da diğer kadınları alaya almasın. Belki onlar kendilerinden daha iyidirler. Birbirinizi karalamayın, birbirinizi (kötü) lakaplarla çağırmayın. İmandan sonra fasıklık ne kötü bir namdır! Kim de tövbe etmezse, işte onlar zalimlerin ta kendileridir." 117

Sabit b. Kays'ın kulağında biraz duymama hastalığı vardı. Peygamber'in meclisine geldiği vakit işitsin diye yer açarlardı. Bir gün gelmiş açılın diye Peygamber'in yanına kadar varmıştı. Bir zata "çekil" demişti. O ise aldırmayarak: "Bu kim? diye sordu. O zat da "ben filanım" diye cevap verdi. $O$ ise "hayır sen filan kadının oğlusun" diye cahiliye döneminde ayıplanan bir kadının ismini zikretti. Adamcağız mahcup oldu. Sabit b. Kays ile alay eden kişi ayetin inişiyle kınanmıştır. ${ }^{118}$

İnananlarca toplumdaki saygınlığı yok edilmeye çalışılanların başında İmam-1 Azam Ebu Hanife gelmektedir. Ebu Hanife, kendilerini peygamberin savunucusu olarak görenler tarafından aşağılanmışır. $O$ birçok konuda selefi yaklaşımdan ${ }^{119}$ farklı fikirlere sahip olduğundan,

115 Schopenhauer, Merhamet, s. 42.

116 İbn Hişam, es-Sire, II, 410; krş. Hamidullah, İslam Peygamberi, I, 268.

117 Hucurat 49/11.

118 Kurtubi, el-Camî, XIX, 386; Yazır, Hak Dini, VI, 4467-4468. İnsanları alay etmeye yönelten psikolojik etkenler içinde büyüklenme, kendini beğenme, karşısındakini küçük ve kusurlu görme gibi hal ve duygular vardır. Sırf gülüp eğlenmek için bir kimse ile alay edilmiş olsa bile alay konusu olan şahsın buna layık görülmesi ve aşağılanması söz konusudur.

119 Selefi yaklaşım, inancını tarihin bir önceki döneminin kültürel yapısına bağlamış ve bu dönemin mutlak doğrunun simgesi olduğunu benimsemiş, her çeşit değişim ve gelişmeye karşı düşünce düzeyinde bütün kapıları kapatmış bir zihin dünyasıdır. Başka bir ifade ile Selefilik, İslam’ın ilk iki neslinin görüş, düşünce ve uygulamalarının

\begin{tabular}{|c|c|c|}
\hline 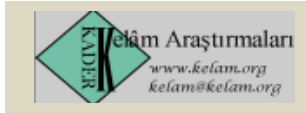 & $\begin{array}{l}\text { Kelâm Araştırmaları Dergisi } \\
\text { Journal of Kalâm Researches } \\
\text { [KADER-e-ISSN: 1309-2030] }\end{array}$ & 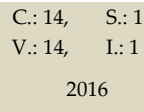 \\
\hline
\end{tabular}


itibarını kaybetmesi için bizzat selef tarafından bi'dat yolunu tutmakla itham edilmiştir. İbn Ebi Şeybe, Ebu Hanife'yi sünnete aykırı davranmakla suçlamıştır. O, "Falan konuda Rasûlullah şöyle buyurdu; Ebu Hanife ise buna zıt olarak şöyle buyurdu" demek suretiyle onu, elçiye karşı biri olarak gösterme çabasına girişmiştir. ${ }^{120}$ Savunucular tarafından Kur'an'ın mahlûk olup olmadığı ile ilgili olarak da şirkle suçlanmıştır. ${ }^{121}$ İnsan bir şeylerin doğrusunu anlamak isterse sessiz kalan tarafın bakış açısını da göz önünde tutması gerekir. Sesini duyuran tarafın söze başlayıp son sözü söylemesine izin verilmemelidir. ${ }^{122}$

Günümüzde birçok zulüm din ve peygamber adına yapılmaktadır. Hz. Muhammed bir yandan aleyhinde olan kişilerin saldırılarıyla çarpıtılırken öte yandan bazen de kendini onun savunucusu ilan edenler tarafından eşit derecede çarpıtılmaktadır. Barışın temsilcisi olması gerekenler bütün hünerleri ve kuvvetleriyle insanları silahlar kuşanıp savaş boruları çalmaya tahrik etmeyi sürdürdüğü sürece kalıcı barışın sağlanması ${ }^{123}$ mümkün olmasa gerektir.

Müslümanlardan bazıları Allah'ın ayetlerini alaya almaktadırlar. “...Sakın Allah'ın ayetlerini eğlenceye almayın. Allah'ın üzerinizdeki nimetini, size ögüt vermek için indirdiği Kitab'ı ve hikmeti hatırlayın. Allah'a karşı gelmekten sakının..."124 Ayetleri anlamada ve ayetlerde belirtilen şeylerle amel etmede ciddi olunmalıdır. Ne yazık ki Müslümanlar arasında geçmişe ve geleneğe karşı hep bir öykünme var olagelmiştir. Unutulmamalıdır ki geçmişe karşı nostalji duyan kişi hayatının esiri haline gelecektir. Geçmiş onu esir aldığı takdirde, içinde bulunduğu zamanda yaşaması engellenecek ve geleceğe bakamayacaktır. ${ }^{125}$

Kendi zihniyetine uymayanları tekfir eden Harici zihniyetin ${ }^{126}$ etkileri günümüzde de devam etmektedir. İnsanlar birtakım gerekçelerle kâfir

gelenekselleşmiş biçimidir. Bu algıya göre söz konusu nesiller, Müslüman tarihinin değil, İslam dinin bir parçasıdır. Akbulut, Ahmet, Sahabe Dönemi İktidar Kavgası, s. 283. Bu konuda geniş bilgi için bkz. İşcan, Mehmet Zeki, Selefilik; İslami Köktenciliğin Tarihi Temelleri, (İstanbul: Kitap Yayınevi, 2014), s. 98-113.

121 Eş'ari, Ebu'1 Hasan Ali b. İsmail, el-íbane an Usulü'd-Diyane, (Beyrut: Dâru İbn Zeydun, ts.), s. 29

122 Toynbee, Hatıralar: Tanıdiklarm, s.286.

123 Locke, Hoşgörü Üstüne Bir Mektup, s.78

124 Bakara 2/231.

125 Toynbee, Hatıralar: Tanıdıklarım, s.228.

126 Başlangıçta, siyasi görüş ayrılığından doğarak, dini nitelik kazanan bu düşünce, siyasi, ahlaki ve toplumsal alanlarda farklılaşarak, Müslümanların mezheplerinden biri oldu. Aslında, “Cemel ve Sıffın olaylarına karışan her grup, kendi açısından haklı olduğunu göstermek için, dini gerekçeler ileri sürmüşlerdir." Ancak karşı tarafı, eylem ve karalarından dolayı İslam dininden çıkmakla suçlayan, kendileri gibi düşünmeyen Müslümanları kâfir sayan ve sistemli bir şekilde "İslam'da tekfir hareketini ilk başlatan" hariciler olmuştur. $\mathrm{Bu}$ konuda o kadar sert davranıyorlardı ki, diğer dinlerin mensuplarına gösterdikleri hoşgörüyü, Müslümanların kadın ve çocuklarından

\begin{tabular}{|ccc} 
Kelâm Araştırmaları Dergisi & C.: 14, & S.: 1 \\
Journal of Kalâm Researches & V.: 14, & I.: 1 \\
[KADER-e-ISSN: 1309-2030] & 2016
\end{tabular}


olarak adlandırılmakta, sonrasında da öldürülmektedir. Cinayet kavramını katillerin işledikleri kötülüklerden ve bu kötülüklerin suçsuz zihinlerce kınanmasından ayrı tuttuğunuz vakit bu kavram anlamsız hale gelir.127 Nasıl tek bir yaprak bütün bir ağacın sessiz bilgisi olmadan sararmazsa cinayet işleyen de diğer insanların gizli iradeleri olmaksızın cinayet işleyemez. ${ }^{128}$ Şayet kâfirlerin zorla dine bağlanmaları gerekiyorsa bunu Allah göksel ordularıyla kolaylıkla yapardı. Eğer batıl itikatlar Allah'a karşı bir saldırı ise, bunlarla uğraşmak, aslında O'nun kendisine ait bir iş ${ }^{129}$ olsa gerektir.

Şayet insan başkalarına karşı şiddet uygulayacaksa o zaman kurbanlarla özel ilişki kurmuş olmamalıdırlar. Muhatabını kâfir olarak görmek bunun en kolay yoludur. Arnold Toynbee bu durumu şu şekilde örneklendirmektedir: "Mesela İngiltere'de Almanlar hakkında edindiğimiz fikri insani boyutundan siyırmamız gerekiyordu. Almanlardan "Huns" şeklinde bahsederek onları toptan öldürürken aklen rahatsızlık duymayacaktık." 130 Ceza ile insanların inançlarını değiştirmek mümkün olsa bile, bu yöntem ruhları kurtuluşa erdiremez. ${ }^{131}$

Müslümanların temel ortak paydalarından birisi Peygamber sevgisidir. Hz. Peygamber'e yönelik olduğu bilinen bir saygısızlığın, her Müslümanı bir şekilde rahatsız etmesi; bütün Müslümanların tepkisine yol açması son derece doğaldır. İçeriden bakıldığında, anlamlı ve anlaşılabilir bir tavır olduğu kolaylıkla söylenebilir. Müslümanların tepkilerini ortaya dökmelerinin de, küreselleşmenin boyutları düşünülürse, yerinde olduğu görülebilir. Sorun, tepki koymakta değil; tepkinin şeklinde ve dozunu ayarlayıp, ayarlayamamaktadır. Hele bu gösterilerde Müslümanların ölmesini, kiliselere, büyükelçilikleri saldırılmasını; her türlü şiddet içeren tavır ve tutumları anlamak mümkün değildir.

Yüce Allah, insanlığa zaman kazandırmak için vahiy göndermiştir. Ayrıca belirli sebeplere sahip olanın avantaj kazanacağı, bir başkasının ise diğerinin ona sahip olması sebebiyle avantajları ele geçirme ümidini keseceği şartları belirleyen hükümler ortaya koymuştur. Bütün bunlara rağmen herkes tabiatının meylettiği, hayatı için gerekli gördüğü, istifade edeceğini umduğunun peşinden koşmaktadır. Bu da insanlar arasında çekişme ve

esirgiyorlardı. Akbulut, Ahmet, Sahabe Dönemi Iktidar Kavgası, (Ankara: Otto Yayınları, 2015), s. 209.

127 Toynbee, Hatıralar: Tanıdıklarım, s.131.

128 Cibran, Ermiş, s.59.

129 John Bagnell Bury, Düşünme ve Konuşma Özgürlüğ̈̈, çev. Mahmut Özdil, (İstanbul: Sayfa Yayınlar1, 2010), s. 84-85.

130 Toynbee, Hatıralar: Tanıdıklarım, s.282.

131 Bury, Düşünme ve Konuşma Özgürlü̆̆̈̈, s. 83. Mutluluk ve neşe içinde yaşayan binlerce insan tek bir kişinin ıstırabını ve ölüm acısını dindiremez. Tıpkı bunun gibi kişinin hali hazır mutluluğu daha önceki ıstıraplarını da dindiremez. Schopenhauer, Hayatın Anlamı, s. 37 .

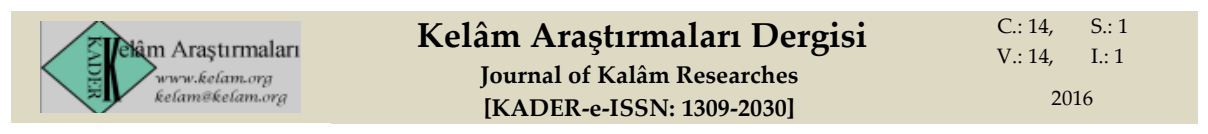


düşmanlığa sebep olmaktadır. Bunların hepsi de insanları savaşa ve birbirini yok etmeye sevk etmektedir. ${ }^{132}$

\section{Sonuç}

İnanmayanlarca alaya alınmak ve aşağılanmak ezilen insanlarda ve Müslümanlarda neredeyse bir kadere dönüşmüştür. Peygamberlerin pek çoğu da bu durumla karşılaşmıştır. Onlar bu tür provoke edici davranışlar karşısında oyuna gelmemişlerdir. Fırsat ellerine geçtiğinde bile istihza silahını muhataplarına karşı kullanmamışlardır.

Yüce yaratıcının kulu olduğunu kabul eden her insan özelliklede Müslüman her şeyden önce Hz. Peygamber gibi her türlü şiddetten nefret etmelidir. İnanan insan başkasına acı çektirmemeli, acı vermekten zevk duymamalıdır. Çünkü acı çekenleri izlemek teorideki, acı vermekten zevk almak ise pratikteki bir kötülük olsa gerektir.

İnsanın dindar olma özgürlüğü olduğu gibi, ateist olma özgürlüğü de vardır. Dilerse bu ikisi arasında bir konumda da olabilir. Ancak aşırı uçtakilerin yaptıklarından tüm dünya insanları etkilenmektedir. Bugün dünyanın küçücük bir köşesinde olanlar aynı anda her yerde yankı bulmaktadır. İnsan nerede yaşarsa yaşasın öfke ve şüphe tarafından yönlendirilmeye karşı koyabilmelidir. Her türlü aşırı uç tarafından onların kendi amaçları doğrultusunda yönlendirilmeye izin vermemelidir.

Normal şartlarda bütün zor kullanma yetkisi yargıya aittir. Hiçbir özel şahsın, haksız bir zorbalık karşısında veya kendini savunma durumunda kalmadıkça hiçbir zaman zor kullanmaması gereklidir. İlahi vahyin yahut yasaların kapsamadığı bir an oldu mu, o alanda insanın kötülüğü ve umursamazlığı hemen çoğalacaktır. Bunun sebebi ise, insanın bencilliği ve kötülüğüdür. İnsanların vicdanlarına hükmedilmediğinde ve saldırılmadığında, onların inandıkları gibi yaşamalarının önündeki engeller kaldırıldığında, insanların önü açıldığında her şey değilse bile çok şeyin düzeldiği görülecektir.

Dünyada yaşayan bütün farklı inançlara sahip olan bazı inananların dar görüşlülüğü, şüphe yok ki, mutsuzluğun ve içinde bulunulan kargaşanın temel sebebidir. Her birey kendi ebedi mutluluğu için gayret göstermelidir. Bunun elde edilmesi ne başka bir insanın çalışıp çabalamasıyla kolaylaşır, ne böyle bir şeyin yokluğu başkalarına zarar verebilir, ne de dışarıdan şiddet uygulayarak ondan bu umut alınabilir. Hem Mekke hem de Medine döneminde istihza yöntemi kullanılarak Müslümanlardan bu umut alınmaya çalışılmıştır. Ancak bunda başarılı olunamamıştır.

Bugün gelinen noktada ise Müslüman kalabalıkları hurafelerin esir aldığıdır. Çünkü kalabalıkları, hurafelerden daha iyi hiçbir şey yönetemez. Bu tür

132 Nesefi, Ebu'l Muin, Kitabü't-Temhid li Kavaidi't-Tevhid, tahk. Habibullah Hasan Ahmed, (Kahire: Dar'u-Tabâatü'1-Muhammediyye, 1986), s. 230.

\begin{tabular}{|ccc|}
\hline Kelâm Araştırmaları Dergisi & C.: 14, & S.: 1 \\
Journal of Kalâm Researches & V.: 14, & I.: 1 \\
\hline [KADER-e-ISSN: 1309-2030] & 2016
\end{tabular}


insanlar, zihinlerine içinde doğruların da bulunduğu yanlış düşünceler aktarılarak kandırılmaktadır. $\mathrm{Bu}$ yöntemi kullananlar tarafından karşısındaki kişiyi doğru bildiğinden vazgeçirmek onu bir takım yanlış emeller için kullanmak çok kolay olmaktadır. İnananlar bu gidişatı ıslah etmek için basmakalıplığın, aceleci kararların ötesine geçmek durumundadır. İyi niyetle, temiz bir inanışla Hz. Peygamber'i bir bütün olarak görmek durumundadırlar. Gördügü insana saygısı olmayan bireyin görmediği Allah'a saygısı olmayacağı açıktır. 


\section{Kaynakça}

Abduh, Muhammed, Tefsirü'l-Menar: Tefsiru'l-Kur'an'il-Azim, haz. Muhammed Reşid Rıza, Kahire: Daru'l-Menar, 1947.

Abdülbaki, M. Fuad, el-Mu'cemu'l-Müfehres li Elfazi'l-Kur'ani'l-Kerim, İstanbul: Çağrı Yayınları, 1990.

Akbulut, Ahmet, Sahabe Dönemi İktidar Kavgası, Ankara: Otto Yayınları, 2015.

Aliyyü'l-Kari, Er-Ravdu'l-Ezher Fi Şerhi'l-Fıkhi'l-Ekber, haz. Şeyh Vehbî Süleyman Gavcî, Beyrut: Daru'l-Beşairi'l-İslamiyye, 1998.

Aydın, Hüseyin, “Meleklere İman”, İslam İnanç Esasları, ed. Ş. Ali Düzgün, Ankara: Grafiker Yayınları, 2013, s. 123-146.

Bury, John Bagnell, Düşünme ve Konuşma Özgürlü̈̆̈̈, çev. Mahmut Özdil, İstanbul: Sayfa Yayınları, 2010.

Callinicos, Alex, Eşitlik, çev. Öncel Sencerman, Ankara: BilgeSu Yayınları, 2014.

Cibran, Halil, Ermiş, çev. İlyas Aslan, İstanbul: Kaknüs Yayınları, ts.

Çağrıcı, Mustafa, "İstihza”, TDV İslam Ansiklopedisi (DİA), XXIII, 347-348.

Ebu Davud, Süleyman b. Eş'as; Kitabu's-Sünen, Beyrut: Müessesetü'rReyyan, 1998.

Eş'ari, Ebu'1 Hasan Ali b. İsmail, el-ïbane an Usulü'd-Diyane, Beyrut: Dâru İbn Zeydun, ts.

Firuzabadi, Mecduddin Muhammed b. Yakub, el-Kamusu'l-Muhit, Misır: ElHeyetül-Misriyytü'l-Ammetü Li'i-Kitabi, 1978.

Hamidullah, Muhammed, İslam Peygamberi, çev. Salih Tŭ̆, Ankara: Yeni Şafak Yayını, 2003.

Izutsu, Toshihiko, Kur'an'da Dini ve Ahlâkî Kavramlar, çer. Selâhattin Ayaz, İstanbul ts.

İbn Hişam, Ebû Muhammed Abdülmelik, es'Siretü'n-Nebeviyye, tahk. Mustafa es-Sakkâ, Misır: ts.

İbn Manzur, Ebi'l-Fadl Cemaleddin Mükerrem b. Mükerrem el-Efrikı elMisri, Lisanü'l-Arab, Beyrut: ts.

İbn Sa'd, Muhammed, et-Tabakâtü'l-Kübrâ, tahk. Dr. Ali Muhammed Ömer, Kahire: Mektebetü'l-Hanci, 2001.

İbn Teymiyye, Şeyh'ul-İslam, Takribü Sarim'il-Meslul Alâ Şatimi'r-Rasul, haz. Salih Es-Savi, y.y.: Daru'1-i'lami'd-Düveli, 1995.

İsfehani, Ragıb, el-Müfredat fi Garibü'l-Kur'an, nşr. Muhammed Seyyid Kîlânî, Beyrut: Daru'l-Ma'rife, ts.

\begin{tabular}{|ccc} 
Kelâm Araştırmaları Dergisi & C.: 14, & S.: 1 \\
Journal of Kalâm Researches & V.: 14, & I.: 1 \\
[KADER-e-ISSN: 1309-2030] & 2016
\end{tabular}


İşcan, Mehmet Zeki, Selefilik; İslami Köktenciliğin Tarihi Temelleri, İstanbul: Kitap Yayınevi, 2014.

Kurtubi, Ebi Abdillah Muhammed b. Ahmed b. Ebi Bekir, el-Camiu liAhkami'l-Kur'an, haz. Abdullah b. Abdu'l-Muhsin et-Türki, Beyrut: Müessesetü'r-Risale, 2006.

Locke, John, Hoşgörü Üstüne Bir Mektup, çev. Melih Yürüşen, Ankara: Liberte Yayınları, 2012.

Maturidi, İmam Ebu Mansur Muhammed b. Muhammed b. Mahmud, Tevilatü Ehli Sünne, haz. Dr. Mücdi Bâsellum, Beyrut: Daru'1-Kütübi'1İlmiyye, 2005.

Nesefi, Ebu'l Muin, Kitabü't-Temhid li Kavaidi't-Tevhid, tahk. Habibullah Hasan Ahmed, Kahire: Dar'u-Tabâatü'l-Muhammediyye, 1986.

Özervarlı, M.Said, "Hârikulâde", TDV İslam Ansiklopedisi (DIA), XVI, 181182.

Rousseau, Jean Jacques, İnsanlar Arasındaki Eşitsizliğin Kaynağı, çev. R. Nuri İleri, İstanbul: Say yayınları, 2013.

Schopenhauer, Arthur, Hayatın Anlamı, çev. Ahmet Aydoğan, İstanbul: Say yayıncllı, 6. Baskı, 2014.

Schopenhauer, Arthur, Merhamet, çev. Zekai Kocatürk, İstanbul: Dergâh Yayınları, 3. Baskı, 2014.

Taberi, Ebu Cafer Muhammed b Cerir, Camiu'l-Beyan fi Te'vili'l-Kur'an, haz. Abdullah b. Abdu'l-Muhsin et-Türki, Kahire: Merkezü'l-Buhusi ve'dDiraseti'l-Arabiyyeti ve'1-İslamiyye, 2001.

Toynbee, Arnold Joseph, Hatıralar: Tanıdıklarım, çev. Deniz Öktem, İstanbul: Klasik Yayınları, 2005.

Vâkıdî, Muhammed b. Ömer, Kitâbü'l-Meğâzî̀, haz. M. Jones, Beyrut: Âlemü'l-Kütüp, 1984.

Yazır, Elmalılı Muhammed Hamdi, Hak Dini Kuran Dili, İstanbul: Eser Yayınevi, 1979.

Zemahşeri, Muhammed b. Ömer, el-Keşşaf an Hakaiki Gavamizi't-Tenzil ve Uyuni'l-Ekavil fi Vücuhi't-Te'vil, Beyrut: Daru İhyai't-Türasi'l-Arabiyye, 2003.

\begin{tabular}{|c|c|c|}
\hline $\begin{array}{l}\text { elịm Araştırmalan } \\
\text { wrww.kelam.ong } \\
\text { kefamefefam.org }\end{array}$ & $\begin{array}{c}\text { Kelâm Araştırmaları Dergisi } \\
\text { Journal of Kalâm Researches } \\
\text { [KADER-e-ISSN: 1309-2030] }\end{array}$ & $\begin{array}{ll}\text { C.: } 14, \quad \text { S.: } 1 \\
\text { V.: } 14, \quad \text { I.: } 1 \\
2016\end{array}$ \\
\hline
\end{tabular}

